\title{
Efficient targeted degradation via reversible and irreversible covalent PROTACs
}

Ronen Gabizon ${ }^{1, *}$, Amit Shraga ${ }^{1, *}$, Paul Gehrtz ${ }^{1}$, Ella Livnah ${ }^{1}$, Yamit Shorer ${ }^{2}$, Neta Gurwicz ${ }^{3}$, Liat Avram $^{4}$, Tamar Unger ${ }^{5}$, Hila Aharoni ${ }^{5}$, Shira Albeck ${ }^{5}$, Alexander Brandis ${ }^{6}$, Ziv Shulman ${ }^{3}$, BenZion Katz ${ }^{7}$, Yair Herishanu ${ }^{7}$, Nir London ${ }^{1, \#}$

${ }^{1}$ Dept. of Organic Chemistry, The Weizmann Institute of Science, Rehovot, 7610001, Israel. ${ }^{2}$ Sackler Faculty of Medicine, Tel Aviv University, Tel-Aviv, Israel.

${ }^{3}$ Dept. of Immunology, The Weizmann Institute of Science, Rehovot, 7610001, Israel.

${ }^{4}$ Dept. of Chemical Research Support, The Weizmann Institute of Science, Rehovot 7610001 , Israel.

${ }^{5}$ Structural Proteomics Unit, Department of Life Sciences Core Facilities, The Weizmann Institute of Science, Rehovot 7610001, Israel.

${ }^{6}$ Life Sciences Core Facilities, Weizmann Institute of Science, Rehovot 7610001, Israel

${ }^{7}$ Department of Hematology, Tel Aviv Sourasky Medical Center, Tel Aviv, Israel and Sackler Faculty of Medicine, Tel Aviv University, Tel-Aviv, Israel.

* equal contribution

\# To whom correspondence should be addressed, nir.london@weizmann.ac.il

Keywords: PROTACs, reversible covalent, cyanoacrylamides, BTK, targeted degradation 
Table of Contents for Supplementary Material

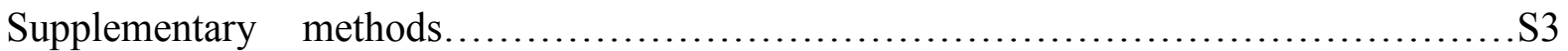

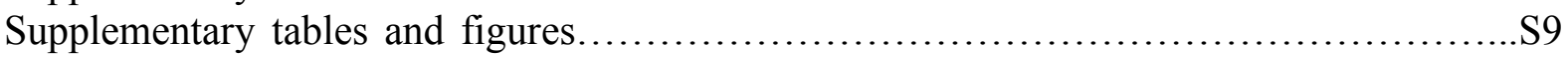

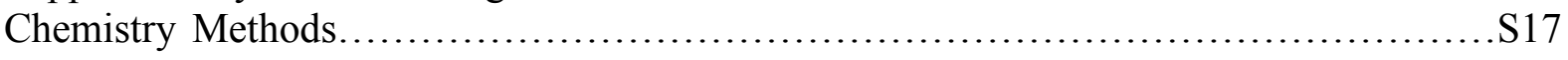




\section{Supplementary Methods}

\section{Cloning and Over Expression of BTK}

Human wild type BTK full length was obtained from the ORFeome (ref: http://www.orfeomecollaboration.org/), from which the full human BTK gene (clone HsCD00433457) was inserted into the mammalian expression vector pCDNA3.1. In parallel, a mutant BTK C481S was constructed by assemble 2 PCR products harboring the desired mutation and cloned into pCDNA3.1. Both constructs contain a C-terminal 6x-His tag and three amino acids sequence (GTK) linker between the BTK coding sequence and the His tag. The expression of hBTK is driven by the CMV promoter. U2OS cells (ATCC HTB-96) were grown to $70 \%$ confluency in a $10 \mathrm{~cm}$ plate, transfected with either hBTK plasmid (BTK WT or C481S) using Lipofectamine 2000 reagent (Thermo Fisher Scientific) according to manufacturer's instructions. Cells were subsequently incubated for 48 hours post transfection, trypsinized and resuspended in $12 \mathrm{~mL}$ medium, and divided $2 \mathrm{~mL}$ per well in a 6-well plates and left to adhere over-night. 72 hours post transfection 100 nM PROTACs were added for 24 hours and BTK was measured by performing western blot procedure as described in the main text.

\section{Expression and Purification of Recombinant BTK}

The expression and purification of human BTK kinase domain (residues 387-659) was based on the method used by Bradshaw JM. et $a l^{1}$. The kinase domain was inserted into pFastBac-1 with an N-terminal $6 \times-$ His tag followed by a TEV protease cleavage site (The plasmid was a gift from Dr. Ville Paavilainen, University of Helsinki). Viruses were produced in Sf9 cells and expression of the BTK kinase domain was subsequently induced in Tni insect cells by infection of $2 \mathrm{~L}$ of cultured cells with 1:200 mL virus solution such that cell growth was terminated after 3 days. The cells were collected by centrifugation ( $800 \mathrm{~g}$ for 15 minutes), and the pellet was resuspended in $50 \mathrm{~mL}$ lysis buffer $(10 \mathrm{mM}$ Hepes, $\mathrm{pH} 7.5,400 \mathrm{mM} \mathrm{NaCl}$, $1.5 \mathrm{mM}$ DTT) supplemented with $1 \times$ protease inhibitor cocktail (Roche). The cells were lysed by five passages through a cell homogenizer. The cellular debris were pelleted by centrifugation $(30,000 \mathrm{~g}$ for 30 minutes). The protein was bound in batch to nickelnitrilotriacetic acid agarose beads in binding buffer (lysis buffer supplemented with $20 \mathrm{mM}$ imidazole) for 4 hours at $4{ }^{\circ} \mathrm{C}$. The beads were washed with additional binding buffer (four 5 $\mathrm{mL}$ washes), and the protein was eluted with four $0.5 \mathrm{~mL}$ portions of elution buffer (lysis buffer 
supplemented with $300 \mathrm{mM}$ imidazole). The His tag was cleaved by the addition of TEV protease with concomitant dialysis overnight into cleavage buffer $(50 \mathrm{mM}$ Tris, $\mathrm{pH} 8.0,0.5$ mM EDTA, $1 \mathrm{mM} \mathrm{DTT}$ ) at $4^{\circ} \mathrm{C}$. The resulting soluble protein was passed over Ni-NTA beads to remove the protease and purified further by gel filtration on a HiLoad_16/60_Superdex_75 (GE Healthcare) column equilibrated with $20 \mathrm{mM}$ Tris, $\mathrm{pH}$ 8.0, $50 \mathrm{mM} \mathrm{NaCl}, 1 \mathrm{mM}$ DTT. The pure protein was then flash-frozen in liquid nitrogen and stored at $-80^{\circ} \mathrm{C}$.

\section{B Cell Activation}

C57BL/6 mice were purchased from Harlan (Rehovot, Israel) and maintained in a pathogen-free facility, experiments were carried on 8-12 weeks old male mice. All experiments with mice were approved by the Weizmann Institute Animal Care and Use Committee.

Splenic cells from C57BL/6 mice were isolated by forcing spleen tissue through mesh into PBS containing 2\% fetal calf serum and $1 \mathrm{mM}$ EDTA and red blood cells were depleted by lysis buffer. Cells were cultured in $96-w e l l$ U-bottom dishes $\left(1 \times 10^{6}\right.$ cells $/ \mathrm{mL}$ in RPMI $10 \%$ FCS $)$ and incubated with BTK PROTACs or Ibrutinib in different concentrations $(1 \mu \mathrm{M}, 100$ $\mathrm{nM}, 10 \mathrm{nM}, 1 \mathrm{nM}, 0.1 \mathrm{nM}$ ) for 24 hours at $37^{\circ} \mathrm{C}$ in $5 \%$ humidified $\mathrm{CO}_{2}$ incubator. Following a 24 hours incubation, cells were stimulated with anti-IgM overnight $(5 \mu \mathrm{g} / \mathrm{mL}$, SigmaAldrich). Subsequently, cells were stained with anti-B220 (clone RA3-6B2, Biolegend) and anti-CD86 (clone GL-1, Biolegend) antibodies for 30 minutes at $4^{\circ} \mathrm{C}$. Single cell suspensions were analyzed by a flow cytometer (CytoFlex, Beckman Coulter).

\section{Proteomics}

Cells were analyzed by intensity based, label-free mass spectrometry based proteomics. Sample preparation: $10^{6}$ Ramos cells were treated in four replicates with either compound or DMSO for 24 hours. Cells were then washed twice by centrifuge at $200 \mathrm{rcf}, 4^{\circ} \mathrm{C}$ for 5 minutes, removing the supernatant and washed with ice cold PBS. Samples were then centrifuged at 200 rcf, $4^{\circ} \mathrm{C}$ for 5 minutes, then supernatant was removed and samples were frozen at $-80^{\circ} \mathrm{C}$. Samples were dispersed in $75 \mu 1$ of $50 \mathrm{mM}$ ammonium bicarbonate, and transferred to $1.8 \mathrm{~mL}$ glass vials. $75 \mu \mathrm{l}$ of $10 \%$ SDS in $50 \mathrm{mM}$ ammonium bicarbonate were added and the samples were heated to $96^{\circ} \mathrm{C}$ for 6 minutes. The samples were sonicated thoroughly in a sonication bath until the DNA was sheared as indicated by reduction in viscosity to level enabling easy pipettation. Total protein concentration was estimated using BCA assay and $30 \mu \mathrm{g}$ from each sample was taken for the experiment. 
The samples were reduced by the addition of $1 / 20$ volume of $100 \mathrm{mM}$ DTT and heating to $60^{\circ} \mathrm{C}$ for 45 minutes. The samples were cooled to room temperature, and $1 / 20$ volume of $200 \mathrm{mM}$ iodoacetamide was added and the reaction was performed in the dark for 30 minutes.

At this point, $1 / 10$ volume of $12 \%$ phosphoric acid was added, followed by 6 volume of $90 \%$ methanol in $50 \mathrm{mM}$ ammonium bicarbonate. The samples were loaded on S-trap Micro columns (Protify), and washed 3 times with $90 \%$ methanol in $50 \mathrm{mM}$ ammonium bicarbonate. The columns were spun without washing to dry the methanol. Then, $1 \mu \mathrm{g}$ of trypsin (Promga) in $20 \mu \mathrm{l}$ of $50 \mathrm{mM}$ ammonium bicarbonate was added to each column, and they were incubated at $47^{\circ} \mathrm{C}$ for 1.5 hours. Then, $40 \mu \mathrm{l}$ of $50 \mathrm{mM}$ ammonium bicarbonate was added and the sample was eluted and another $0.5 \mu \mathrm{g}$ of trypsin was added, followed by overnight incubation at $37^{\circ} \mathrm{C}$. The columns themselves were further eluted with $40 \mu 10.2 \%$ formic acid in water, followed by $40 \mu \mathrm{l}$ of $0.2 \%$ formic acid in $50 \%$ acetonitrile:water, to elute strongly bound peptides. This elution was stored at $4^{\circ} \mathrm{C}$ and combined the next day with the first elution. The samples were then dried by SpeedVac and analyzed.

Liquid chromatography: ULC/MS grade solvents were used for all chromatographic steps. Each sample was loaded using split-less nano-Ultra Performance Liquid Chromatography (10 kpsi nanoAcquity; Waters, Milford, MA, USA). The mobile phase was: A) $\mathrm{H} 2 \mathrm{O}+0.1 \%$ formic acid and B) acetonitrile $+0.1 \%$ formic acid. Desalting of the samples was performed online using a reversed-phase Symmetry C18 trapping column (180 $\mu \mathrm{m}$ internal diameter, $20 \mathrm{~mm}$ length, $5 \mu \mathrm{m}$ particle size; Waters). The peptides were then separated using a T3 HSS nano-column (75 $\mu \mathrm{m}$ internal diameter, $250 \mathrm{~mm}$ length, $1.8 \mu \mathrm{m}$ particle size; Waters) at $0.35 \mu \mathrm{L} /$ minute. Peptides were eluted from the column into the mass spectrometer using the following gradient: $4 \%$ to $30 \% \mathrm{~B}$ in 150 minutes, $35 \%$ to $90 \%$ B in 5 minutes, maintained at $90 \%$ for 5 minutes and then back to initial conditions.

Mass Spectrometry: The nanoUPLC was coupled online through a nanoESI emitter (10 $\mu \mathrm{m}$ tip; New Objective; Woburn, MA, USA) to a tribrid Orbitrap Fusion Lumos mass spectrometer (Thermo Scientific) using a PicoView nanospray apparatus (New Objective). Data was acquired in data dependent acquisition (DDA) mode, using a top-speed method with maximum cycle time of $3 \mathrm{sec}$. MS1 resolution was set to 120,000 (at $200 \mathrm{~m} / \mathrm{z}$ ), mass range of $375-1650 \mathrm{~m} / \mathrm{z}$, AGC of $4 \mathrm{e} 5$ and maximum injection time was set to $50 \mathrm{msec}$. MS2 was performed by HCD in the Orbitrap with resolution set to 15,000, quadrupole isolation $1 \mathrm{Th}$, AGC of 5e4, and maximum injection time of $100 \mathrm{msec}$. 
Raw data were analyzed using the MaxQuant software suite 1.6.0.16 (www.maxquant.org) with the Andromeda search engine ${ }^{2}$. The higher-energy collisional dissociation (HCD) MS/MS spectra were searched against an in silico tryptic digest of Homo sapiens proteins from the UniProt/Swiss-Prot sequence database (v. July 2019), including common contaminant proteins. All MS/MS spectra were searched with the following MaxQuant parameters: acetyl (protein N-terminus) and methionine oxidation as variable modifications; cysteine carbamidomethylation was set as fixed modification for all samples, except for the SDT samples in which case carbamidomethylation was set as variable modification; max 2 missed cleavages; and precursors were initially matched to $4.5 \mathrm{ppm}$ tolerance and $20 \mathrm{ppm}$ for fragment spectra. Peptide spectrum matches and proteins were automatically filtered to a $1 \%$ false discovery rate based on Andromeda score, peptide length, and individual peptide mass errors. Processing was conducted without a match between runs.

Proteins were identified and quantified based on at least two unique peptides and based on the label-free quantification (LFQ) ${ }^{3}$ values reported by MaxQuant. Every data set contained three sets of four replicates (one set for DMSO treated samples, one set for $50 \mathrm{nM}$ and one set for $100 \mathrm{nM}$ ). Proteins were excluded from analysis if within all three sets, there were less than three samples with directly detected and quantified protein. After this filtering step, missing values were replaced from a normal distribution.

\section{Metabolomics}

Sample preparation: $10^{6}$ Ramos cells were treated in three replicates with $100 \mathrm{nM}$ compound for 2 hours. Cells were then washed twice by centrifuge at $200 \mathrm{rcf}, 4^{\circ} \mathrm{C}$ for 5 minutes, removing the supernatant and washed with ice cold PBS. Samples were then centrifuged at $200 \mathrm{rcf}, 4^{\circ} \mathrm{C}$ for 5 minutes, then supernatant was removed and samples were frozen at $-80^{\circ} \mathrm{C}$. Samples were dispersed in $100 \mu \mathrm{l}$ of PBS. From each sample, $20 \mu 1$ were mixed with $20 \mu \mathrm{l}$ of $10 \% \mathrm{SDS}$ in $50 \mathrm{mM}$ ammonium bicarbonate, heated to $96^{\circ} \mathrm{C}$ for 5 minutes, and the protein concentration was measured by BCA assay. Another $75 \mu 1$ were mixed with $0.5 \mathrm{~mL}$ of $50 \%$ acetonitrile:water, sonicated 3 times 10 seconds on ice, centrifuged for 10 minutes at $15000 \mathrm{rpm}$ at $4^{\circ} \mathrm{C}$, and the supernatant was transferred to a new tube and lyophilized. The residue was dissolved in $25 \%$ acetonitrile in water in a volume calculated from the BCA assay to obtain a concentration equivalent to $1.09 \mu \mathrm{g} / \mu 1$ protein. The samples were centrifuged at $21,000 \mathrm{~g}$ for 5 minutes to remove insoluble material. Standard curves from $0.1-100 \mathrm{ng} / \mathrm{mL}$ for each compound were used for quantitation. 
The LC-MS/MS instrument consisted of an Acquity I-class UPLC system (Waters) and Xevo TQ-XS triple quadrupole mass spectrometer (Waters) equipped with an electrospray ion source. Chromatographic separation was done on UPLC BEH C18 column $(50 \mathrm{~mm} \times 2.1 \mathrm{~mm}$, $1.7-\mu \mathrm{m}$, Waters) using $50-100 \%$ gradient of $95 \%$-aqueous acetonitrile with $0.1 \%$ formic acid in aqueous $0.1 \%$ formic acid during 2.5 minutes, with a flow rate of $0.3 \mathrm{~mL} \mathrm{~min}^{-1}$ and column temperature $30^{\circ} \mathrm{C}$. Samples kept at $10^{\circ} \mathrm{C}$ were automatically injected in a volume of $3 \mu$ l.

MS parameters (positive ion mode): capillary voltage $-2.0 \mathrm{kV}$, source temperature $150^{\circ} \mathrm{C}$. MRM transitions, $\mathrm{m} / \mathrm{z}$ (collision energy, $\mathrm{eV}$ ): $970.3>84.0(62), 970.3>301.0(47)$ and $970.3>304.0$ (57) for RC-2; $945.2>84.0$ (75), $945.2>301.0$ (50) and $945.2>304.2$ (68) for IR-2; $947.2>84.0$ (70), $947.2>304.1$ (72) and $947.2>387.0$ (50) for NC-1; and 998.2>84.0 (75), $998.2>301.0(55)$ and $998.2>304.1$ (70) for RC-3.

\section{Targeting BTK in CLL cells}

\section{Patients and samples}

After signing an informed consent form approved by the Tel Aviv Medical Center IRB according to the Helsinki Accords, blood samples were collected from patients fulfilling the standard criteria for CLL. Peripheral blood mononuclear cells (PBMC) were isolated by Ficoll (Uppsala, Sweden) density-gradient centrifugation. Viable frozen cells were kept in FCS (Biological Industries, Beit-Haemek, Israel) containing 10\% DMSO (Merck, Darmstadt, Germany) and stored in liquid nitrogen. Before use, frozen cells were thawed and cultured at $37^{\circ} \mathrm{C}, 5 \% \mathrm{CO}_{2}$, in RPMI medium supplemented with $10 \% \mathrm{FCS}$, penicillin, streptomycin, and L-glutamine (all from Biological Industries, Beit-Haemek, Israel.)

\section{Antibodies and Reagents}

Anti-BTK antibody was purchased from Cell Signaling Technology (Beverly, MA) and anti-actin form MP Biomedicals (Illkirch, France). Goat anti Rabbit IgG (H+L)-HRP conjugate and Goat anti Mouse IgG $(\mathrm{H}+\mathrm{L})-\mathrm{HRP}$ conjugate were from Jackson ImmunoResearch laboratories (West Grove, PA). All antibodies utilized in the study were used in concentrations according to the manufacturer's instructions.

\section{Degradation Experiments and Western Blotting}

CLL cells $\left(20 \times 10^{6} / \mathrm{mL}\right)$ were incubated with PROTACs, at the indicated doses, at $37^{\circ} \mathrm{C}$ for 18 hours. The PROTACs were dissolved in DMSO, and controls were treated with DMSO accordingly. 
Following incubation with PROTACs as detailed, cells were collected and lysed in cell lysis buffer (Cell Signaling Technology, Beverly, MA) containing Phosphatase Inhibitor Cocktail 2 and protease inhibitor Cocktail (Sigma-Aldrich, St. Louis, MO). Extract from cell lysates were separated on 4-15\% Criterion ${ }^{\mathrm{TM}} \mathrm{TGX}^{\mathrm{TM}}$ Precast Midi Protein Gel (BioRad), and transferred electrophoretically to nitrocellulose paper. The nitrocellulose paper was incubated with the designated antibodies and HRP conjugated secondary antibodies according to the manufacturer's instructions. Bands were detected using MyECL Imager (Thermo Scientific, Rockford, IL). 
Supplementary Tables and Figures:

Supplementary Table 1: Reversible covalent BTK PROTAC library

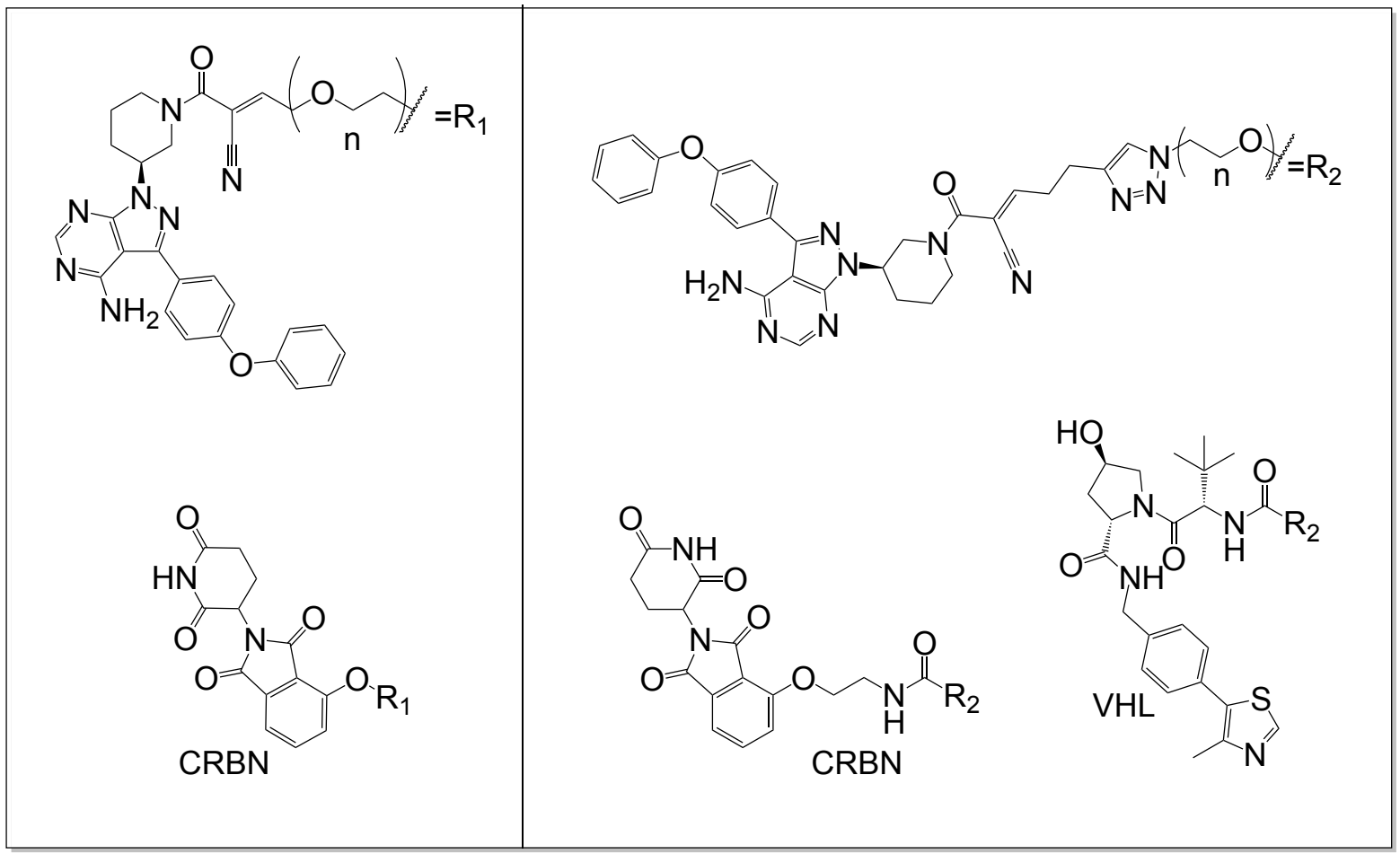

Direct PEG linkage

Triazole Linkage

\begin{tabular}{|c|c|c|c|}
\hline Compound & E3 binder & Linker size (n=) & Linker Chemistry \\
\hline PG37 (RC-0a) & $\mathrm{R}_{1}=\mathrm{CRBN}$ & 4 & Direct PEG \\
\hline PG27 (RC -1) & $\mathrm{R}_{1}=\mathrm{CRBN}$ & 5 & Direct PEG \\
\hline PG15 (RC -0b) & $\mathrm{R}_{1}=\mathrm{CRBN}$ & 3 & Direct PEG \\
\hline RG16 (RC -0c) & $\mathrm{R}_{2}=\mathrm{VHL}$ & 6 & Triazole \\
\hline RG15 (RC -0d) & $\mathrm{R}_{2}=\mathrm{VHL}$ & 4 & Triazole \\
\hline RG14 (RC -0e) & $\mathrm{R}_{2}=\mathrm{VHL}$ & 3 & Triazole \\
\hline RG13 (RC -0f) & $\mathrm{R}_{2}=\mathrm{VHL}$ & 2 & Triazole \\
\hline RG12 (RC -0g) & $\mathrm{R}_{2}=\mathrm{CRBN}$ & 4 & Triazole \\
\hline RG11 (RC -0h) & $\mathrm{R}_{2}=\mathrm{CRBN}$ & 3 & Triazole \\
\hline RG10 (RC -0i) & $\mathrm{R}_{2}=\mathrm{CRBN}$ & 2 & Triazole \\
\hline RG8 (RC -0j) & $\mathrm{R}_{2}=\mathrm{CRBN}$ & 6 & Triazole \\
\hline
\end{tabular}


A

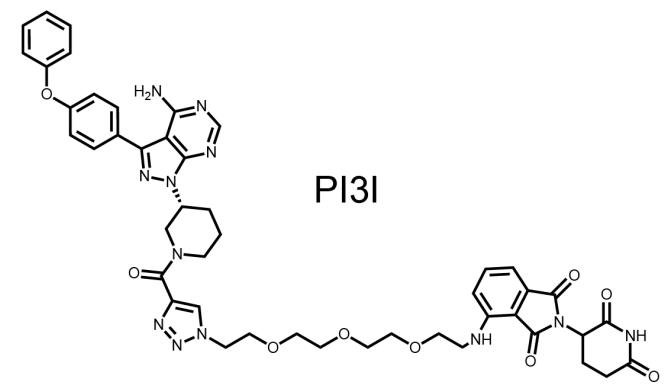

B

PROTAC 24h $[\mu \mathrm{M}]$ :

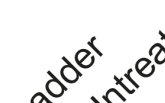

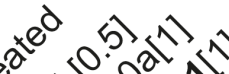

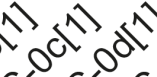

तो

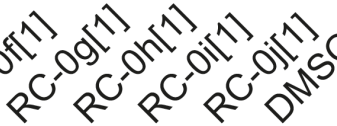

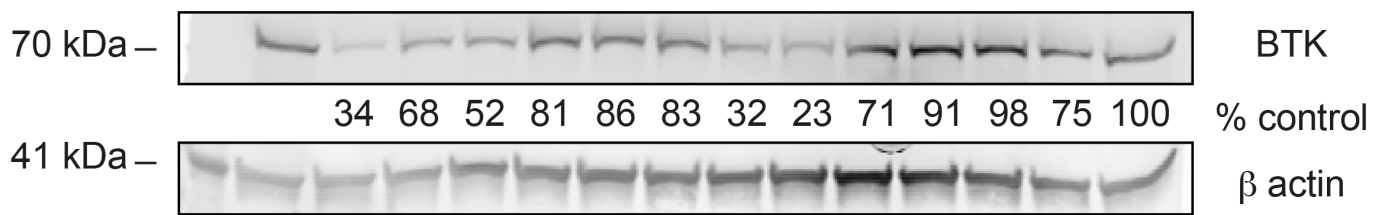

C

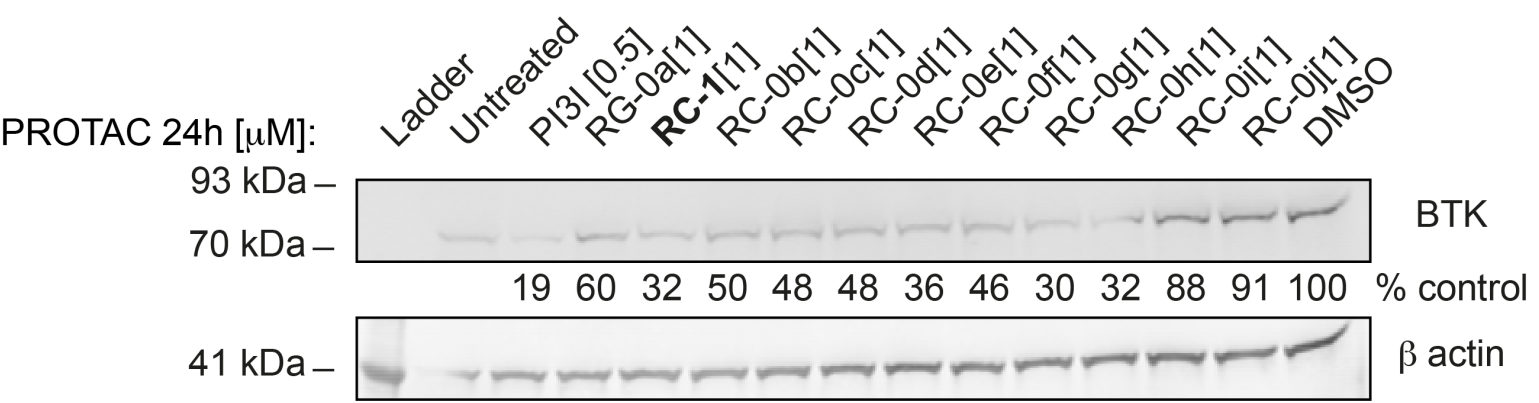

\section{Supplementary Figure 1: Library screen for BTK PROTACs highlights RC-1 as a} prominent PROTAC.

A. Chemical structure of PI3I, a previously reported non-covalent BTK PROTAC ${ }^{4}$.

B. Western blot of Mino cells treated with the reversible covalent library of BTK PROTACs.

C. Western blot of K562 cells treated with the reversible covalent library of BTK PROTACs. 
A

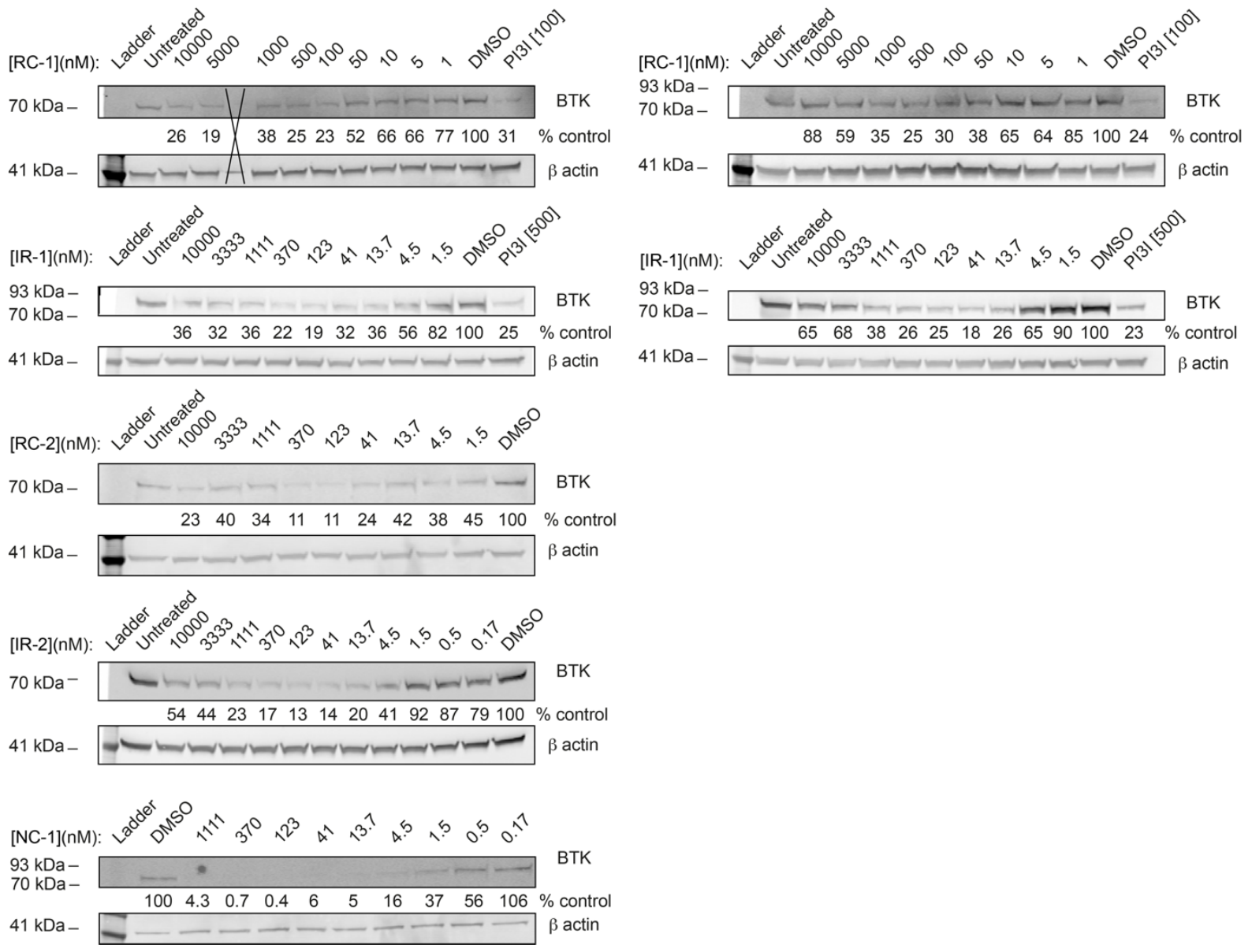

B

\section{Supplementary Figure 2: BTK degradation by PROTACs}

A. Western blot depicting a full dose-response curve for PROTACs in Ramos cell lines.

B. Western blot depicting a full dose-response curve for PROTACs in Mino cell lines.

Both experiments are after $24 \mathrm{~h}$ incubations with the PROTACs.

Supplementary Table 2: Metabolomic quantification of PROTACs cellular concentration

\begin{tabular}{|c|c|}
\hline PROTAC & $\begin{array}{c}\text { Effective cellular concentration } \\
\text { (pg compound / } \boldsymbol{\mu g} \text { total protein) }\end{array}$ \\
\hline NC-1 & $8.6 \pm 2.6$ \\
\hline IR-2 & $4.1 \pm 0.7$ \\
\hline RC-2 & $0.93 \pm 0.06$ \\
\hline RC-3 & $10.7 \pm 3.1$ \\
\hline
\end{tabular}




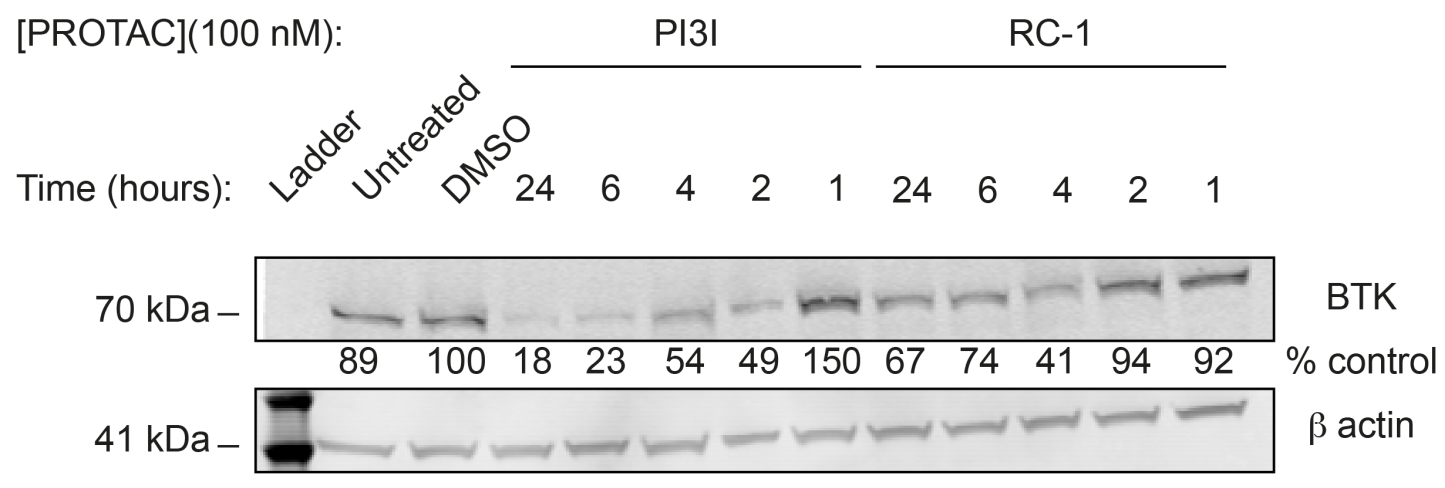

[PROTAC](100 nM):

IR-1

RC-2

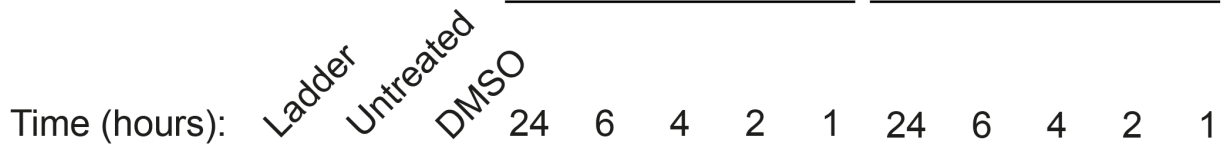

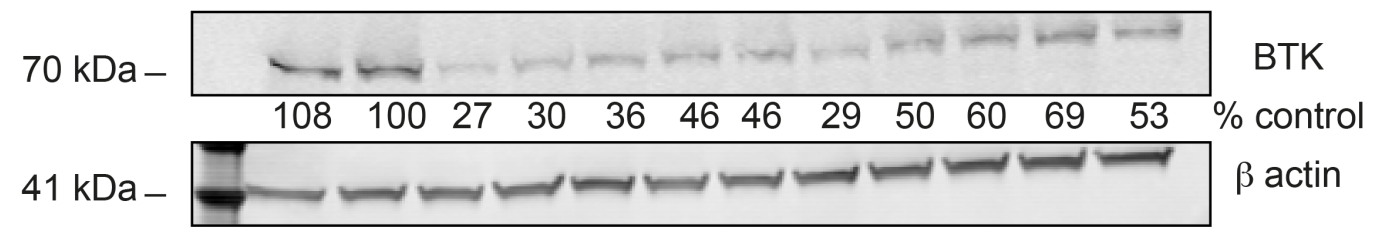

[PROTAC](100 nM): $\quad$ IR-2

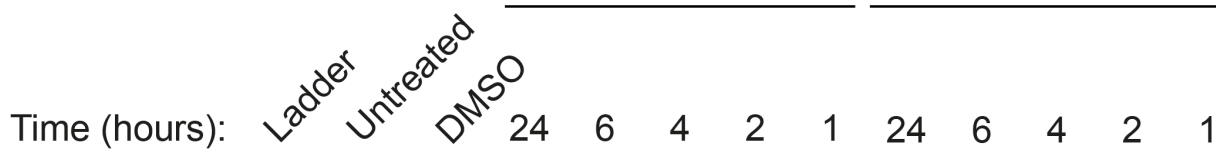
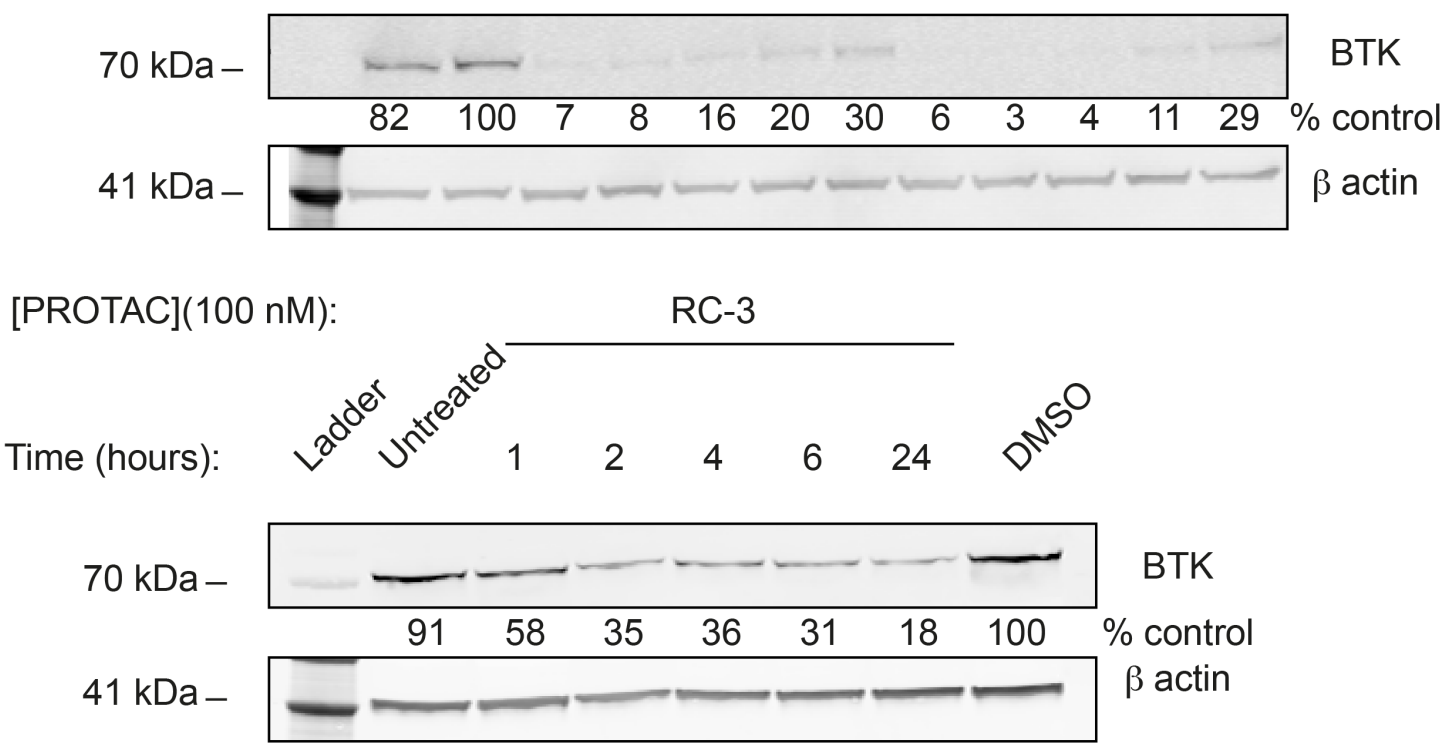

\section{Supplementary Figure 3: BTK degradation time dependency.}

Ramos (PI3I, RC-1, IR-1, RC-2, IR-2, NC-1) or Mino (RC-3) cells were treated with 100 $\mathrm{nM}$ of PROTAC or DMSO for indicated times, subsequently harvested for BTK levels measurement via western blot. 

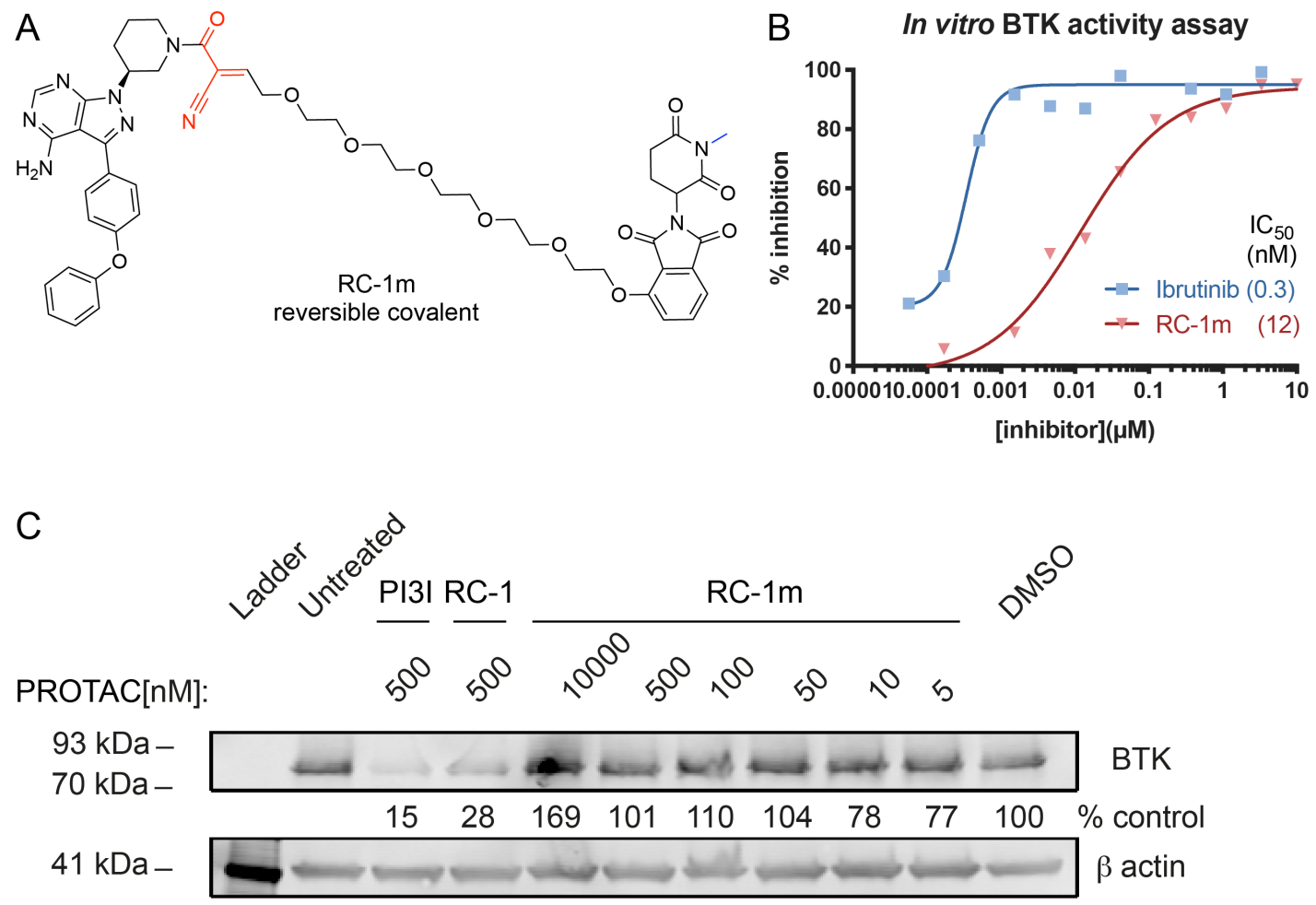

Supplementary Figure 4: Reversible covalent PROTAC induced degradation is mediated by CRBN.

A. Structure of RC-1m, an analog of RC-1, with a methylated (blue) CRBN binder, that abrogates CRBN binding.

B. In vitro kinase assay in the presence of Ibrutinib or RC-1m, shows that BTK binding is not hampered by this methylation (compare to RC-1 in Fig. 2A)

C. Western blot depicting a full dose-response curve for $\mathbf{R C - 1 m}$ in Mino cell lines, shows no apparent degradation. 


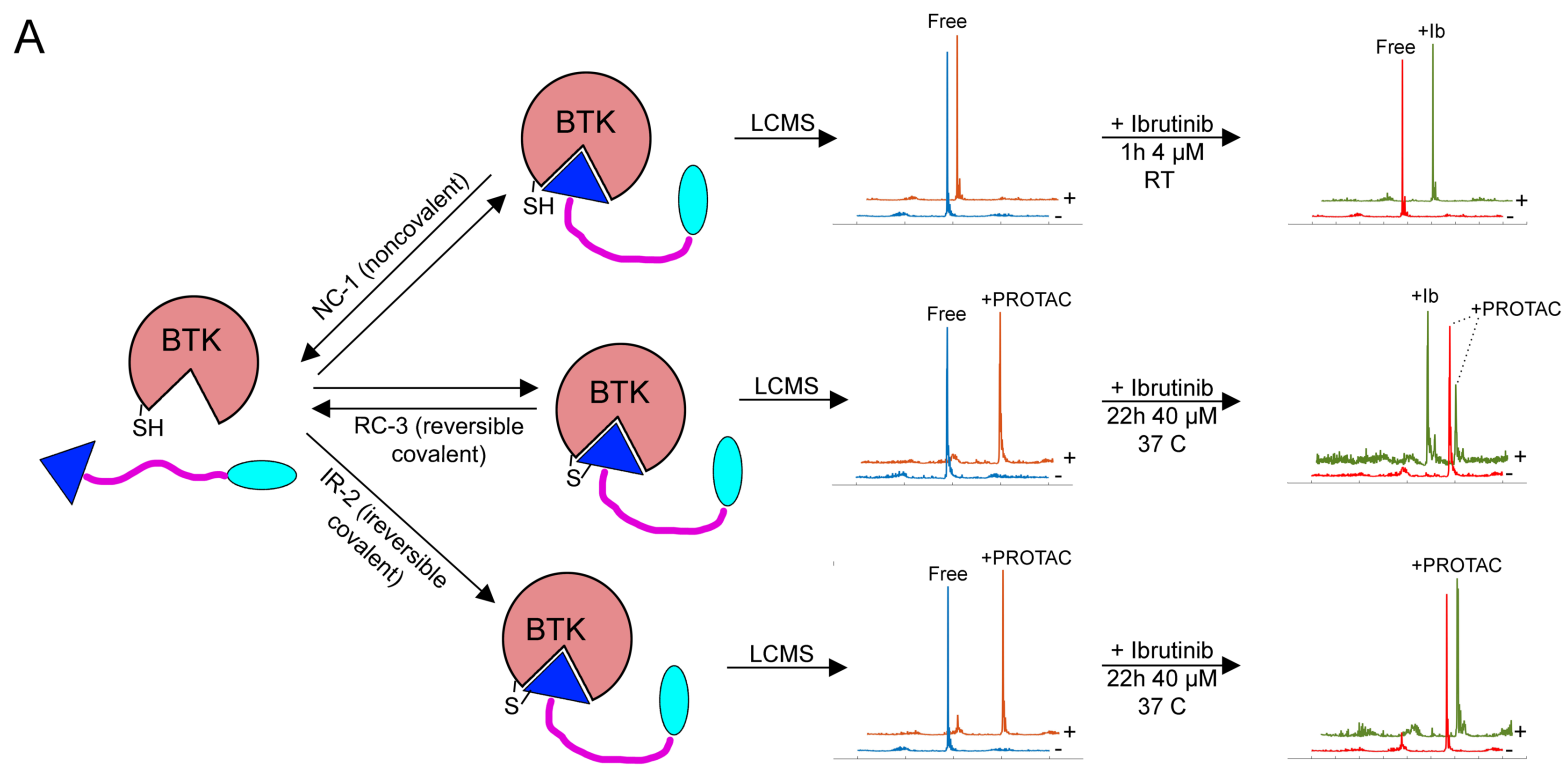

B
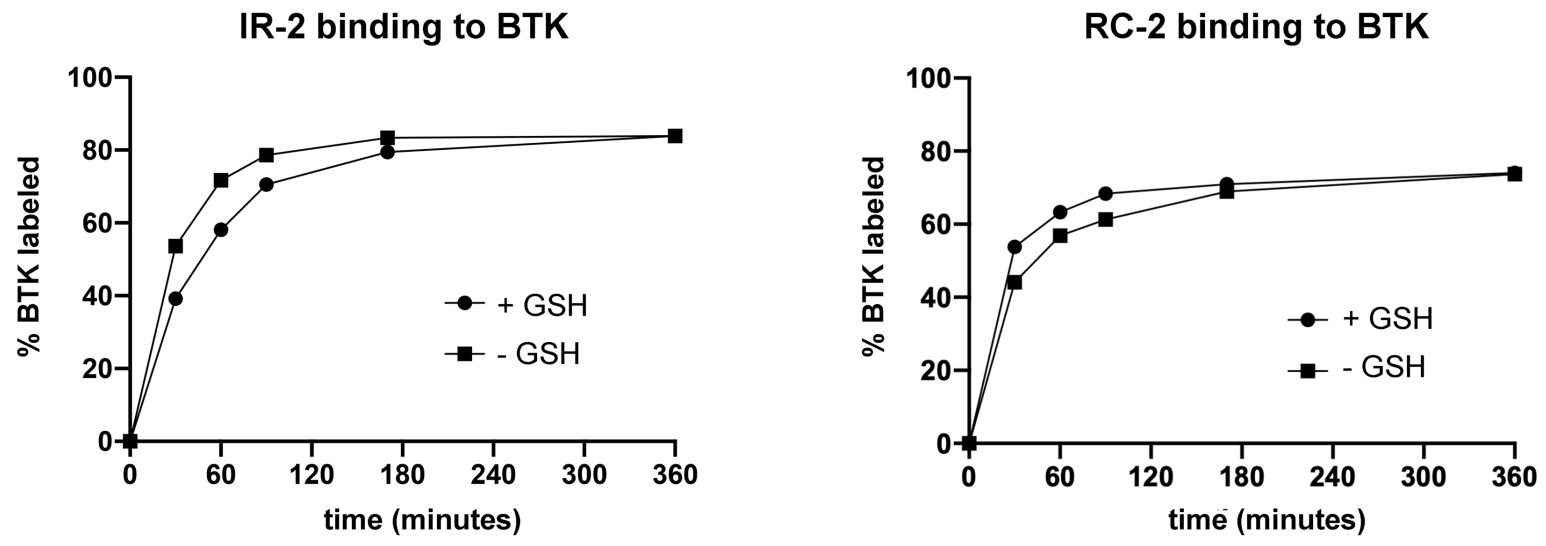

\section{Supplementary Figure 5: Kinetic studies of BTK labeling using LC/MS}

A. BTK was incubated with $3 \mu \mathrm{M}$ compound for 2 hours at $25^{\circ} \mathrm{C}$, followed by addition of Ibrutinib and incubation at indicated times and temperatures. Samples were analyzed before and after addition of Ibrutinib by intact LC/MS at indicated times.

B. Binding experiments in the presence of glutathione. Compounds $(4 \mu \mathrm{M})$ were incubated with glutathione $(6.14 \mathrm{mM})$ in assay buffer for 30 minutes, followed by addition of BTK to 2 $\mu \mathrm{M}$ (which diluted the compounds to $3.25 \mu \mathrm{M}$ and the glutathione to $5 \mathrm{mM}$ ) and monitoring of the binding reaction by LC/MS. 

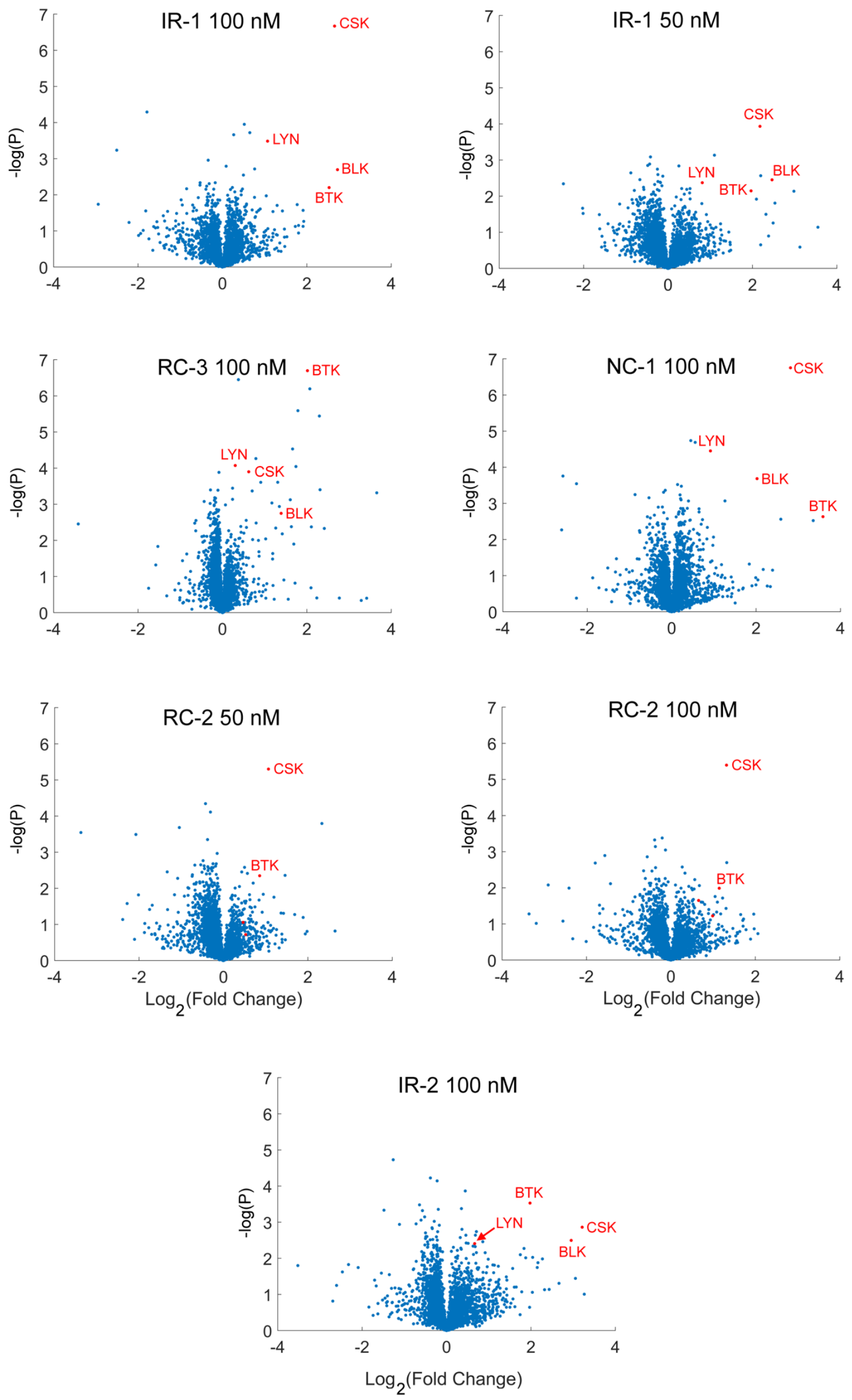
Supplementary Figure 6: Proteomics analysis reveals high selectivity for both covalent and non-covalent BTK PROTACs.

Ramos cells were incubated with each PROTAC or DMSO in quadruplicates for $24 \mathrm{~h}$ at the designated concentrations, and were then subjected to label-free quantitative proteomics analysis. Each graph plots the $\log _{2}$ fold-change of proteins in the treated samples compared to the DMSO controls (X-axis) vs. the - $\log (\mathrm{p}$-value) of that comparison in a student's T-test (Yaxis).

\section{Primary B-cells response to BTK PROTACs}

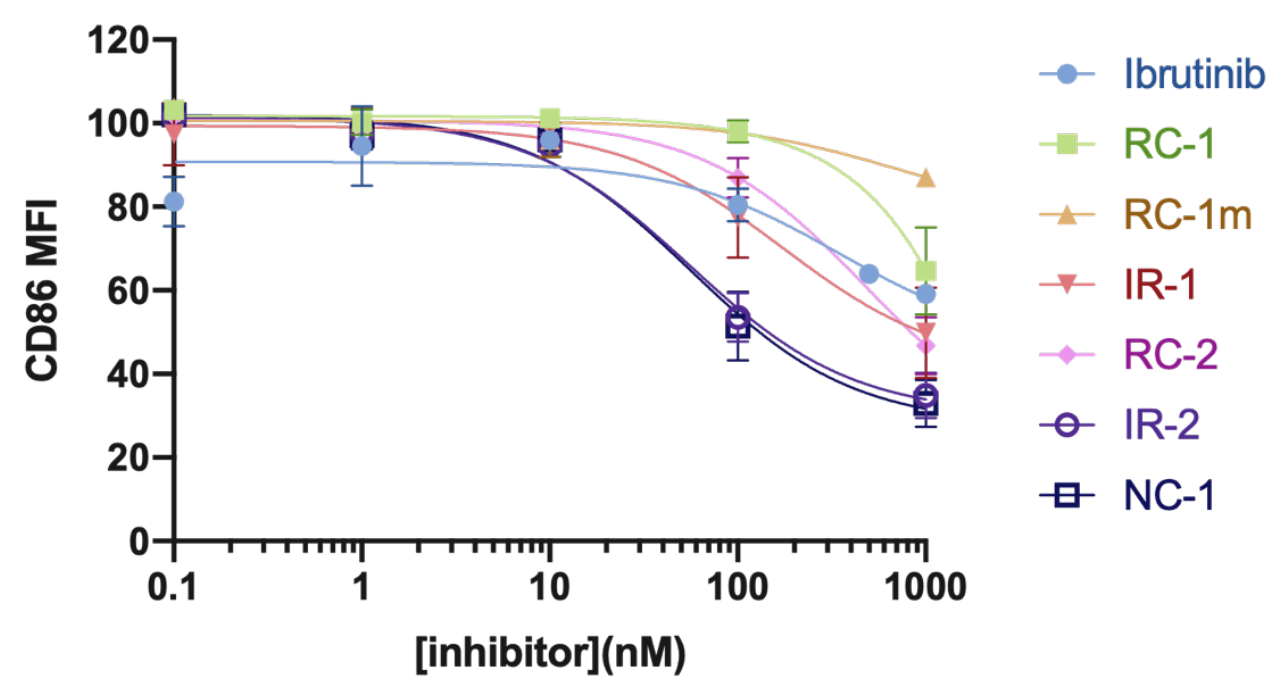

Supplementary Figure 7: PROTACs inhibit B cell receptor signaling more potently than Ibrutinib.

Dose response curves for $\mathrm{B}$ cell response after anti-IgM induced activation and treatment with BTK PROTACs or Ibrutinib for 24 hours. The Y-axis shows normalized CD86 Mean fluorescence intensity, where $100 \%$ activation is cells stimulated with anti-IgM, and $0 \%$ activation is unstimulated cells. 


\section{Chemistry Methods:}

\section{Materials: were purchased from the following vendors}

- BTK inhibitor (free amine), CAS 1022150-12-4: purchased from BLD pharmatech

- Deuterated solvents: Cambridge isotope laboratories

- Non-modified polyethylene glycol: Broadpharm

- Polyethylene glycol (azide-NHS ester): BiochemPEG

- Solvents: Sigma Aldrich

- Other reagents - Sigma Aldrich

\section{Chemistry outline:}

The synthesis of the compounds used in this study is outlined in scheme 1 .
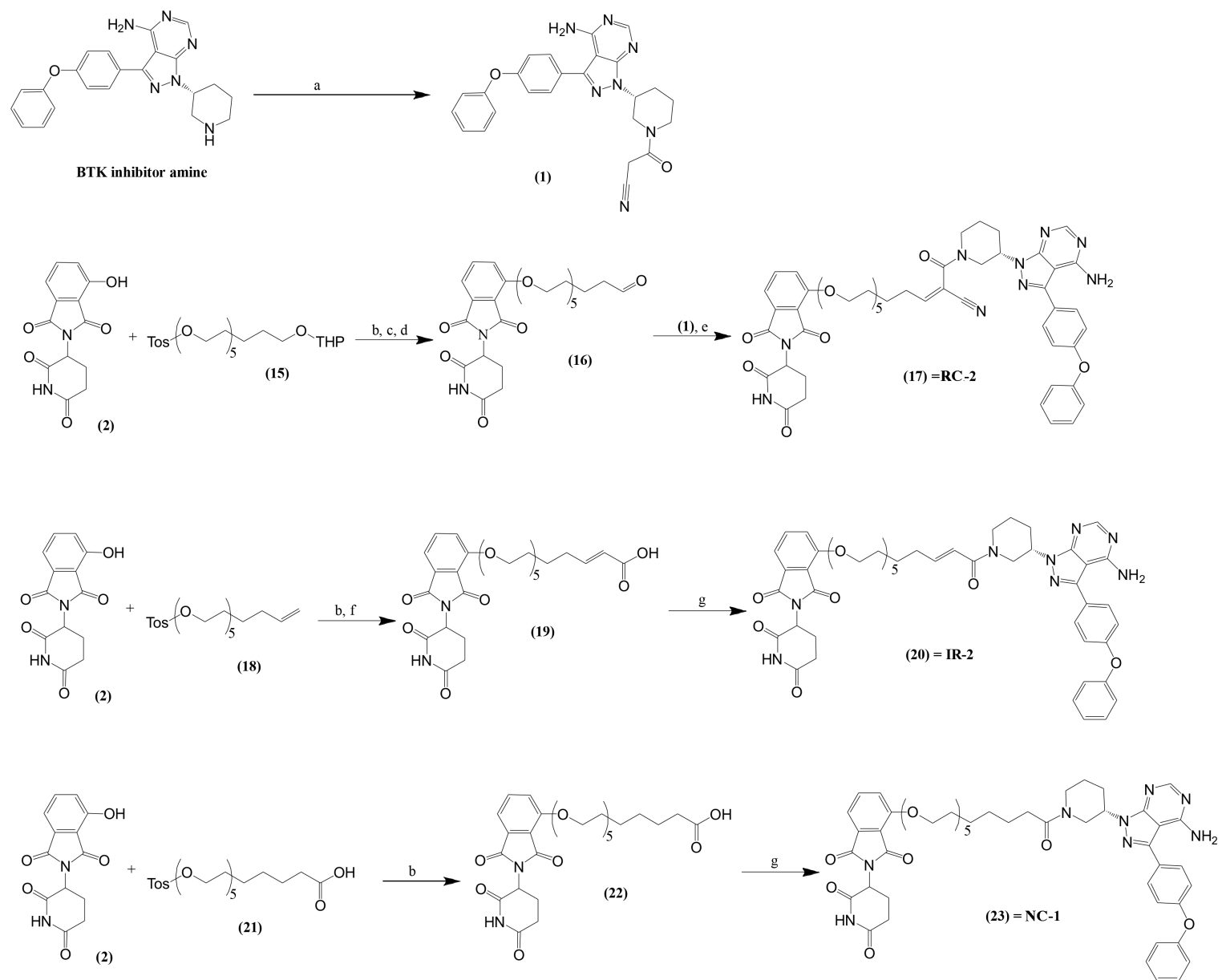

Scheme 1: synthetic scheme: (a) cyanoacetic acid/EDC/DIEA, DCM, RT (b) $\mathrm{Na}_{2} \mathrm{CO}_{3} /$ DMF, $100^{\circ} \mathrm{C}$ (c) $5 \% \mathrm{TFA} /$ methanol, RT (d) Dess Martin Periodinane / DCM, $50^{\circ} \mathrm{C}$ (e) $\mathrm{Na}_{2} \mathrm{CO}_{3} /$ pyridine, $50^{\circ} \mathrm{C}$ (f) acrylic acid + Grubbs $2^{\text {nd }}$ gen. $/ \mathrm{THF}, 50^{\circ} \mathrm{C}(\mathrm{g})$ EDC/DIEA/Hobt in DCM, RT 
(R)-3-(3-(4-amino-3-(4-phenoxyphenyl)-1H-pyrazolo[3,4-d]pyrimidin-1-yl)piperidin-1-yl)-3oxopropanenitrile:

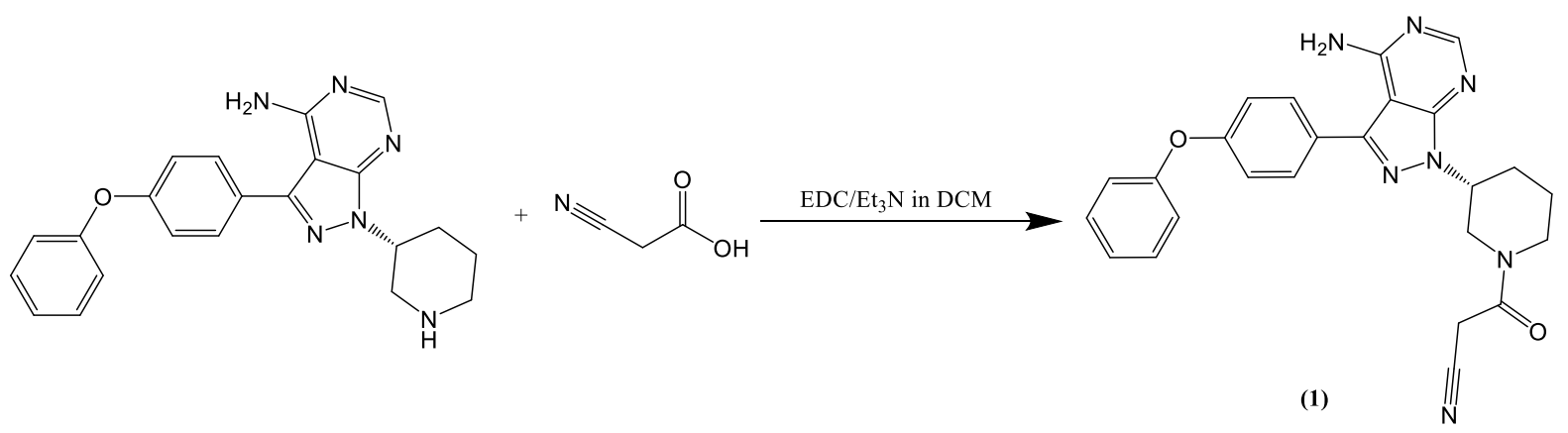

Cyanoacetic acid (1.94 mmol, $165 \mathrm{mg})$, was dissolved in $10 \mathrm{~mL}$ dry dichloromethane. The reaction was cooled on ice and $3.2 \mathrm{mmol}$ EDC hydrochloride $(614 \mathrm{mg})$ and $7.7 \mathrm{mmol}$ of triethylamine $(1.07 \mathrm{~mL})$ was added. After 10 minutes $1.29 \mathrm{mmol}$ BTK inhibitor free amine (498 $\mathrm{mg}$ ) was added and the reaction was warmed to room temperature. After 2 hours the reaction was washed twice with $1 \mathrm{M} \mathrm{HCl}$, followed by two washes with $5 \% \mathrm{NaHCO}_{3}$, drying over sodium sulfate and evaporating. This yielded $\mathbf{1}$ as a light brown low density powder, 510 mg (yield 95\%).

HR-MS (m/z): Calculated: 453.19; Found: $454.1998[\mathrm{M}+\mathrm{H}]^{+}, 476.1815[\mathrm{M}+\mathrm{Na}]^{+}$.

${ }^{1} \mathrm{H}$ NMR (500 MHz, Acetonitrile-d 3 ) $\delta 10.95$ (br s, $\left.1 \mathrm{H}\right), 8.35$ (s, $1 \mathrm{H}$, minor rotamer set A), 8.33 (s, 1H, major rotamer set A), $7.69-7.65(\mathrm{~m}, 2 \mathrm{H}), 7.46(\mathrm{dd}, \mathrm{J}=8.6,7.3 \mathrm{~Hz}, 1 \mathrm{H}), 7.25-7.20$ $(\mathrm{m}, 2 \mathrm{H}), 7.15(\mathrm{~d}, \mathrm{~J}=7.3 \mathrm{~Hz}, 1 \mathrm{H}), 6.73$ (br s, 1H), 4.99 (tt, J = 9.0, $4.5 \mathrm{~Hz}, 1 \mathrm{H}$, minor rotamer set B), 4.87 (tt, $\mathrm{J}=10.5,4.3 \mathrm{~Hz}, 1 \mathrm{H}$, major rotamer set B), $4.59-4.53$ (m, 1H, major rotamer set C), 4.11 (dt, $\mathrm{J}=13.3,4.5 \mathrm{~Hz}, 1 \mathrm{H}$, minor rotamer set C), $3.91-3.60(\mathrm{~m}, 4 \mathrm{H}), 3.35-3.15$ $(\mathrm{m}, 2 \mathrm{H}), 2.37-2.18(\mathrm{~m}, 4 \mathrm{H}$, major rotamer set $\mathrm{D}), 2.03-1.87(\mathrm{~m}, 4 \mathrm{H}$, minor rotamer set $\mathrm{D})$, $1.85-1.74(\mathrm{~m}, 1 \mathrm{H}$, major rotamer set $\mathrm{E}), 1.69(\mathrm{~m}, 1 \mathrm{H}$, minor rotamer set $\mathrm{E})$.

${ }^{13} \mathrm{C}$ NMR (126 MHz, Acetonitrile-d $\left.\mathrm{d}_{3}\right) \delta 162.3,161.6,161.5,158.8,158.8,156.4,153.7,153.6$, $151.8,146.7,146.4,130.1,130.1,130.1,126.2,126.1,124.1,124.1,119.5,119.5,119.3,117.3$, $115.2,97.3,53.2,52.7,49.2,45.9,45.8,42.0,29.5,29.2,25.1,25.0,23.9,22.6$.

Approximated ratio of amide rotamers from ${ }^{1} \mathrm{H}-\mathrm{NMR}$ integral ratios: 63:37 
<smiles>[NH3+]C1CCC(=O)NC1=O</smiles><smiles>CC(=O)CCCCC(=O)O</smiles><smiles>O=C1CCC(N2C(=O)c3cccc(O)c3C2=O)C(=O)N1</smiles>

$1 \mathrm{~g}$ of 2,6-dioxopiperidin-3-aminium $(6.1 \mathrm{mmol})$ and $1 \mathrm{~g}$ of 4-hydroxyisobenzofuran-1,3-dione ( 1 eq.) were dissolved in acetic acid with 2 equivalents of sodium acetate $(1 \mathrm{~g})$ and refluxed $\left(110^{\circ} \mathrm{C}\right)$ for 12 hours. The solvent was evaporated under reduced pressure, and the residue was washed with ice-cold water and lyophilized. The product was obtained as a brown powder, $1.51 \mathrm{~g}(90 \%$ yield $)$.

HR-MS (m/z): Calculated: 274.06; Found: $297.0492[\mathrm{M}+\mathrm{Na}]^{+}$.

${ }^{1} \mathrm{H}$ NMR (500 MHz, DMSO-d 6 ) $\delta 11.18(\mathrm{~s}, 1 \mathrm{H}), 11.09(\mathrm{~s}, 1 \mathrm{H}), 7.66(\mathrm{t}, \mathrm{J}=7.8 \mathrm{~Hz}, 1 \mathrm{H}), 7.33$ $(\mathrm{d}, \mathrm{J}=7.1 \mathrm{~Hz}, 1 \mathrm{H}), 7.26(\mathrm{~d}, \mathrm{~J}=8.4 \mathrm{~Hz}, 1 \mathrm{H}), 5.08(\mathrm{dd}, \mathrm{J}=12.8,5.4 \mathrm{~Hz}, 1 \mathrm{H}), 2.89(\mathrm{ddd}, \mathrm{J}=$ $17.0,13.8,5.4 \mathrm{~Hz}, 1 \mathrm{H}), 2.66-2.42$ (m, 2H, overlaps with residual DMSO), $2.06-1.98$ (m, $1 \mathrm{H})$.

${ }^{13} \mathrm{C}$ NMR (126 MHz, DMSO-d 6$) \delta 173.3,170.5,167.5,166.3,155.9,136.9,133.6,124.0$, $114.8,114.8,49.1,40.5,40.3,40.2,40.0,39.8,39.7,39.5,31.4,22.5$.

17-hydroxy-3, 6,9,12,15-pentaoxaheptadecyl 4-methylbenzenesulfonate:<smiles>CC(C)(O)CCO[TlH]</smiles>

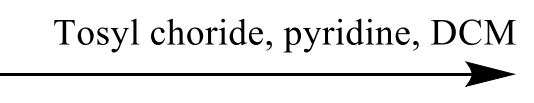<smiles>CCOS(=O)(=O)c1ccc(C)cc1</smiles>

Hexaethyleneglycol (25 g, 90 mmol, 1.0 equiv.) was dissolved in DCM (150 mL), followed by the addition of pyridine ( $3.62 \mathrm{~mL}, 45 \mathrm{mmol}, 0.5$ equiv.). To the stirred solution was added tosyl chloride (8.58 g, $45 \mathrm{mmol}, 0.5$ equiv.) in four batches, each 15 minutes apart. After the last addition, the mixture was stirred for $18 \mathrm{~h}$. The reaction mixture was thoroughly freed from 
DCM using a rotary evaporator. The resulting residue was treated with $0.1 \mathrm{M} \mathrm{HCl}(150 \mathrm{~mL})$. The mixture was extracted twice with hexane $(50 \mathrm{~mL}$ each) to remove excess tosyl chloride. The aqueous layer was washed with three portions of diethyl ether $(20 \mathrm{~mL}$ each) to remove the ditosylated byproduct, and the extracts were checked by TLC to avoid premature extraction of the monotosylate. The aqueous layer was extracted with three portions of DCM (50 mL each). The combined organic layers were washed with $0.1 \mathrm{M} \mathrm{HCl}(50 \mathrm{~mL})$, dried over MgSO4, filtered and freed from solvent by rotary evaporation to give the product as a colourless oil (13.2 g weighed mass, $28.71 \mathrm{mmol}$ based on 95\% purity by LC/MS, 32\%). Monotosylated PEGs of other length were synthesized using analogous procedures.

HR-MS (m/z): Calculated: 436.18; Found: $437.1845[\mathrm{M}+\mathrm{H}]^{+}, 459.1674[\mathrm{M}+\mathrm{Na}]^{+}$

${ }^{1} \mathrm{H}$ NMR (500 MHz, Chloroform-d) $\delta 7.81(\mathrm{~d}, \mathrm{~J}=8.0 \mathrm{~Hz}, 2 \mathrm{H}), 7.35(\mathrm{~d}, \mathrm{~J}=7.9 \mathrm{~Hz}, 2 \mathrm{H}), 4.17$ (t, J = 4.8 Hz, 2H), $3.77-3.58$ (m, 22H), 3.37 (br s, 1H), 2.46 (s, 3H).

${ }^{13} \mathrm{C}$ NMR (126 MHz, Chloroform-d) $\delta 144.8,133.0,129.8,128.0,72.5,70.7,70.6,70.6,70.5$, $70.5,70.3,69.3,68.7,61.7,21.7$.

Differences in relaxation times between Aryl-H and Alkyl-H lead to incongruent integration results between these two signal sets.

17-((2-(2,6-dioxopiperidin-3-yl)-1,3-dioxoisoindolin-4-yl)oxy)-3,6,9,12,15pentaoxaheptadecanal:

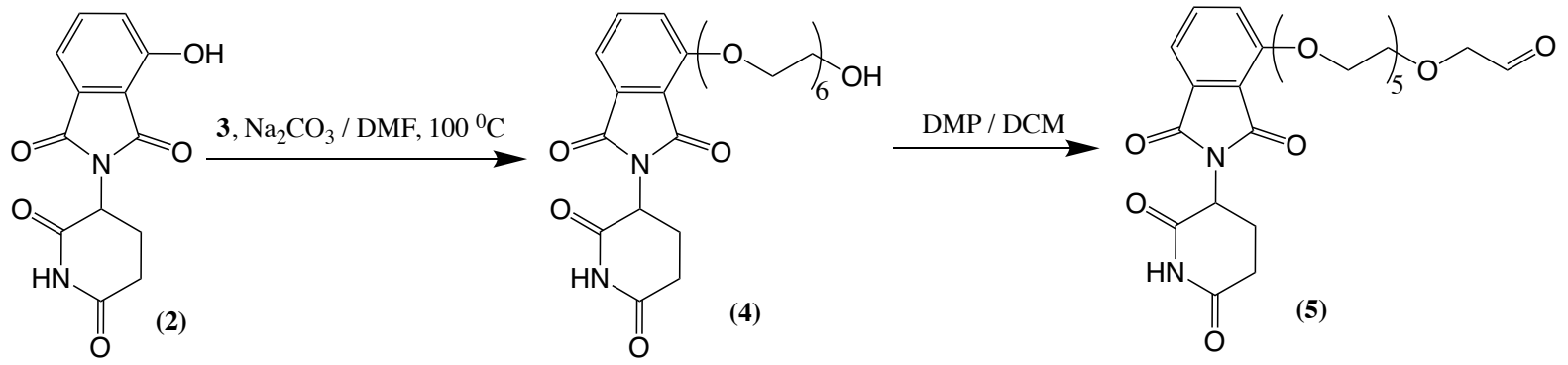

$150 \mathrm{mg}$ of $2(0.547 \mathrm{mmol})$ were dissolved in $1 \mathrm{~mL}$ of dry DMF. 5 equivalents of sodium carbonate $(290 \mathrm{mg})$ were added, and the solution was heated to $100^{\circ} \mathrm{C}$ under argon. 1.5 equivalents of $3(358 \mathrm{mg})$ were dissolved in $250 \mu \mathrm{l}$ dry DMF and added dropwise to the hot solution while stirring. The reaction was stirred for 3.5 hours under argon. The reaction was 
stopped with the addition of $1 \mathrm{~mL}$ acetic acid, and the solvent was evaporated under reduced pressure at $75^{\circ} \mathrm{C}$. The residue was dissolved in $20 \%: 80 \%$ acetonitrile:water $(\mathrm{v} / \mathrm{v})+0.1 \%$ trifluoroacetic acid and purified by reverse phase HPLC, yielding $212 \mathrm{mg}$ of 4 (71\% yield, HRMS (m/z): Calculated: 538.22; Found: $\left.539.2241[\mathrm{M}+\mathrm{H}]^{+}, 561.2076[\mathrm{M}+\mathrm{Na}]^{+}\right)$. Then, $90 \mathrm{mg}$ of $4(0.167 \mathrm{mmol})$ were dissolved in $2 \mathrm{~mL}$ DCM and stirred on ice. 2.2 equivalents of Dess Martin Periodinane $(156 \mathrm{mg})$ were added and the reaction stirred on ice for 15 minutes, followed by 2 hours at room temperature. The resulting solution was filtered and evaporated, and the aldehyde $\mathbf{5}$ was separated from unoxidized alcohol and further oxidized species by HPLC, yielding $23.7 \mathrm{mg}$ of 5 (26\% yield) as a highly viscous pale oil (HR-MS (m/z): Calculated: 536.20; Found: $\left.537.2076[\mathrm{M}+\mathrm{H}]^{+}, 559.1913[\mathrm{M}+\mathrm{Na}]^{+}, 577.2012\left[\mathrm{M}+\mathrm{Na}+\mathrm{H}_{2} \mathrm{O}\right]^{+}\right)$. 
(E)-18-((S)-3-(4-amino-3-(4-phenoxyphenyl)-1H-pyrazolo[3,4-d]pyrimidin-1-yl)piperidine-1carbonyl)-1-((2-(2,6-dioxopiperidin-3-yl)-1,3-dioxoisoindolin-4-yl)oxy)-3, 6,9, 12,15-

pentaoxanonadec-17-ene-19-nitrile:
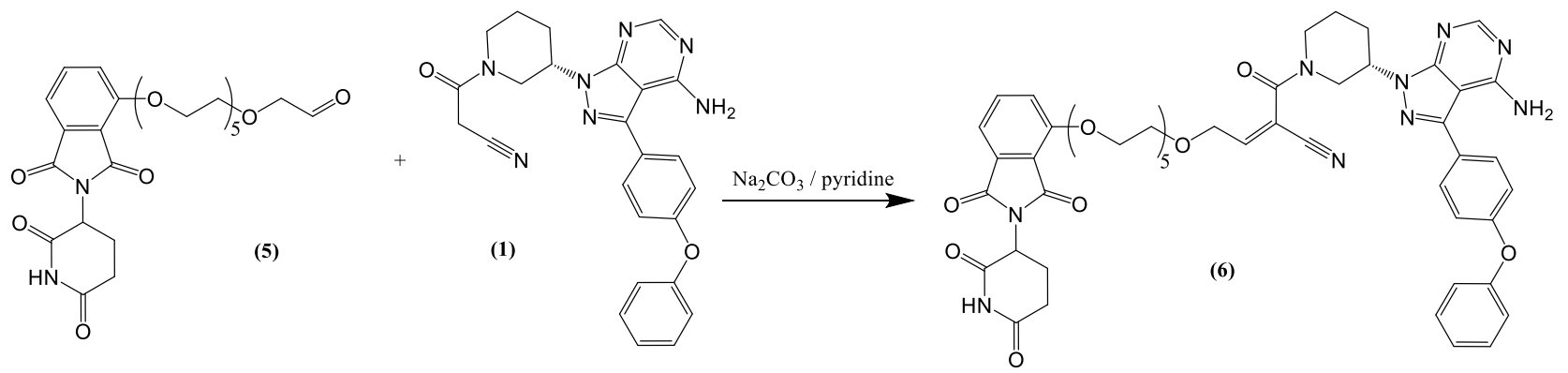

$22 \mathrm{mg}$ of $1(0.0486 \mathrm{mmol})$ were dissolved in $10 \mathrm{~mL}$ of pyridine, and $2.4 \mathrm{mg}$ of sodium carbonate $(0.0226 \mathrm{mmol})$ were added under argon. The aldehyde $5(30.3 \mathrm{mg}, 0.057 \mathrm{mmol})$ was dissolved in pyridine and added to the reaction, which was stirred at $50^{\circ} \mathrm{C}$ for 3.5 hours. Dilute reaction conditions and limited reaction times were essential to avoid reaction of condensation products with 1 to give higher molecular weight adducts. The reaction was stopped by addition of $25 \mathrm{mg}$ citric acid and evaporation of the solvent, followed by purification using HPLC. Obtained 6 as a white powder, $12 \mathrm{mg}$ (25\% yield).

HR-MS (m/z): Calculated: 972.3814; Found: $972.3887[\mathrm{M}+\mathrm{H}]^{+}, 97-94.3701[\mathrm{M}+\mathrm{Na}]^{+}$ ${ }^{1} \mathrm{H}$ NMR (500 MHz, DMSO-d 6 ) $\delta 11.11(\mathrm{~s}, 1 \mathrm{H}, \mathrm{NH}), 8.40$ - 8.27 (m, 1H Ibrutinib-amine-arylH), 7.80 (td, $J=7.9,2.6 \mathrm{~Hz}, 1 \mathrm{H}$, Thalidomide-aryl-H), 7.67 (d, $J=8.1 \mathrm{~Hz}, 2 \mathrm{H}), 7.52(\mathrm{dd}, J=$ 8.6, 5.1 Hz, 1H, Thalidomide-aryl-H), 7.45 (m, 3H), 7.25 - 7.07 (m, 5H, Ph-O-Ibrutinib amine), $6.86-6.24$ (m, 1H, Alkenyl-CH), $5.25-1.38$ (complicated aliphatic region, 36H). Mixture of $\mathrm{E} / \mathrm{Z}$ diastereomers and amide bond rotamers. Heteroaryl- $\mathrm{NH}_{2}$ could not be detected.

${ }^{13} \mathrm{C}$ NMR (126 MHz, DMSO-d 6$) \delta 173.2,170.4,167.3,165.7,164.1,158.8,158.5,157.8$, 156.7, 156.3, 153.6, 150.2, 137.4, 133.7, 130.6, 127.7, 124.3, 120.5, 119.5, 119.4, 116.8, 115.9, $97.6,70.6,70.3,70.3,70.2,70.2,70.2,69.3,69.1,52.7,49.2,46.5,46.0,31.4,29.6,24.3,22.5$. Not all ${ }^{13} \mathrm{C}$ signals could be detected and/or overlapped due to the presence of a hexaethyleneglycol chain. 
3,6,9,12,15-pentaoxaoctadec-17-en-1-yl 4-methylbenzenesulfonate:

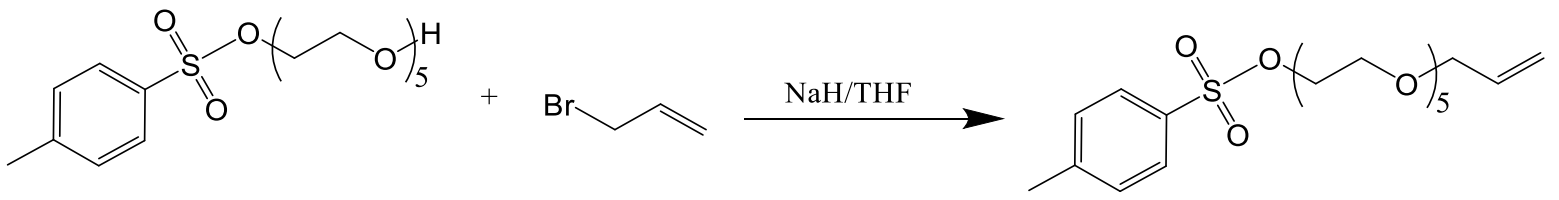

$500 \mathrm{mg}$ of Tos-PEG5-OH (1.29 mmol) was dissolved in dry THF under argon. 2.5 equivalents of allyl bromide were added. The reaction was cooled on ice, and 1.5 equivalents of sodium hydride were added. The solution turned cloudy due to precipitation of sodium bromide. After 20 the reaction was heated to room temperature under argon for 1 hour. TLC using 3\% methanol in chloroform confirmed reaction was complete. The reaction was quenched with 1 $\mathrm{M} \mathrm{HCl}$, the THF was evaporated in vacuo, and the product was extracted 3 times with dichloromethane, washed with $5 \% \mathrm{NaHCO}_{3}$, dried over sodium sulfate, and purified using silica gel chromatography using a gradient of 0 to $10 \%$ methanol in chloroform. Obtained the product as a bright yellow oil, $140 \mathrm{mg}$ (yield 25\%).

HR-MS (m/z): Calculated: 432.18; Found: $433.1888[\mathrm{M}+\mathrm{H}]^{+}, 455.1718[\mathrm{M}+\mathrm{Na}]^{+}$.

${ }^{1} \mathrm{H}$ NMR (500 MHz, Chloroform-d) $\delta 7.81(\mathrm{~d}, \mathrm{~J}=8.2 \mathrm{~Hz}, 2 \mathrm{H}), 7.35$ (d, J = 8.0 Hz, 2H), 5.92 (ddt, $J=17.4,10.4,5.7 \mathrm{~Hz}, 1 \mathrm{H}), 5.28$ (dd, $\mathrm{J}=17.2,1.6 \mathrm{~Hz}, 1 \mathrm{H}), 5.18(\mathrm{dd}, \mathrm{J}=10.4,1.5 \mathrm{~Hz}$, $1 \mathrm{H}), 4.19-4.15(\mathrm{~m}, 2 \mathrm{H}), 4.03(\mathrm{dt}, \mathrm{J}=5.7,1.5 \mathrm{~Hz}, 2 \mathrm{H}), 3.72-3.57(\mathrm{~m}, 18 \mathrm{H}), 2.46(\mathrm{~s}, 3 \mathrm{H})$.

${ }^{13} \mathrm{C}$ NMR (126 MHz, Chloroform-d) $\delta 144.8,134.8,133.0,129.8,128.0,117.1,107.6,106.4$, $77.3,72.2$, 70.7, 70.7, 70.6, 70.6, 70.6, 70.5, 70.5, 69.4, 69.2, 68.7, 67.7, 67.4, 29.5, 29.5, 23.8, 23.8, 21.7.

Differences in relaxation times between Aryl-H, Alkenyl-H and Alkyl-H lead to incongruent integration results between these three signal sets. 
(E)-1-((2-(2,6-dioxopiperidin-3-yl)-1,3-dioxoisoindolin-4-yl)oxy)-3,6,9,12,15-

pentaoxanonadec-17-en-19-oic acid :
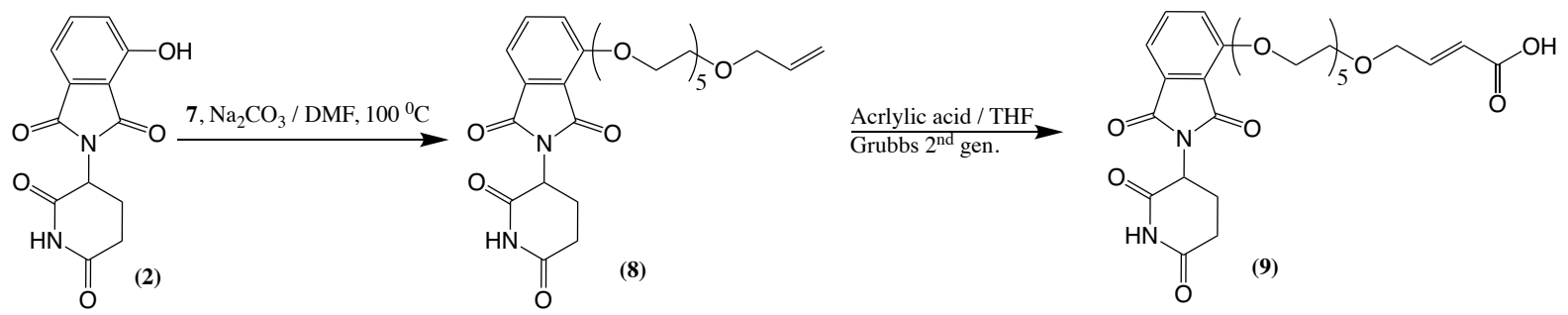

$37.5 \mathrm{mg}$ of $2(0.137 \mathrm{mmol})$ were dissolved in dry DMF under argon. 5 equivalents of sodium carbonate $(69 \mathrm{mg})$ were added and the solution was heated to $100^{\circ} \mathrm{C}$. The tosylate $7(1.2$ equivalents, $71 \mathrm{mg}$ ) was dissolved in DMF and added dropwise to the solution. The reaction proceeded for 2 hours under argon, neutralized with $0.5 \mathrm{~mL}$ of acetic acid, evaporated and purified by HPLC to yield 8 as a pale, viscous oil (51 mg, 70\% yield, HR-MS (m/z): Calculated: 534.32; Found: $\left.535.2280[\mathrm{M}+\mathrm{H}]^{+}, 557.2117[\mathrm{M}+\mathrm{Na}]^{+}\right)$. Then $24 \mathrm{mg}$ of $8(0.045 \mathrm{mmol})$ was dissolved in dry THF, and 30 equivalents of acrylic acid $(92.5 \mu 1)$ were added. 0.05 equivalents of Grubbs catalyst $2^{\text {nd }}$ generation was added, and the reaction proceeded under argon at $40^{\circ} \mathrm{C}$. The solvent was evaporated and the acid 9 was purified by HPLC as a white powder (10.8 mg, $42 \%$ yield).

HR-MS (m/z): Calculated: 578.21; Found: $601.2010[\mathrm{M}+\mathrm{Na}]^{+}$.

${ }^{1} \mathrm{H}$ NMR (500 MHz, DMSO-d 6 ) $\delta 12.32$ (s, 1H), 11.10 (s, 1H), 7.82 (dd, J = 8.5, 7.2 Hz, 1H), $7.54(\mathrm{~d}, \mathrm{~J}=8.5 \mathrm{~Hz}, 1 \mathrm{H}), 7.46(\mathrm{~d}, \mathrm{~J}=7.2 \mathrm{~Hz}, 1 \mathrm{H}), 6.81(\mathrm{dt}, \mathrm{J}=15.7,4.2 \mathrm{~Hz}, 1 \mathrm{H}$, major isomer set A), $6.33(\mathrm{dt}, \mathrm{J}=11.7,5.0 \mathrm{~Hz}, 1 \mathrm{H}$, minor isomer set A), $5.93(\mathrm{dt}, \mathrm{J}=15.7,2.0 \mathrm{~Hz}, 1 \mathrm{H}$, major isomer set $\mathrm{B}$ ), $5.77(\mathrm{dt}, \mathrm{J}=11.7,2.3 \mathrm{~Hz}, 1 \mathrm{H}$, minor isomer set $\mathrm{B}), 5.09(\mathrm{dd}, \mathrm{J}=12.8,5.4 \mathrm{~Hz}$, $1 \mathrm{H}), 4.39-4.32(\mathrm{~m}, 2 \mathrm{H}), 4.17-4.11(\mathrm{~m}, 2 \mathrm{H}), 3.84-3.78(\mathrm{~m}, 2 \mathrm{H}), 3.67-3.62(\mathrm{~m}, 2 \mathrm{H}), 3.56$ $-3.50(\mathrm{~m}, 14 \mathrm{H}), 2.94-2.84(\mathrm{~m}, 1 \mathrm{H}), 2.65-2.52(\mathrm{~m}, 2 \mathrm{H}), 2.07-2.00(\mathrm{~m}, 1 \mathrm{H})$.

${ }^{13} \mathrm{C}$ NMR (126 MHz, DMSO-d 6 ) $\delta$ 173.24, 170.39, 167.31, 167.27, 165.72, 156.31, 145.27, $137.44,133.71,121.57,120.51,116.79,115.85,70.63,70.31,70.29,70.24,70.21,70.18$, $70.07,69.32,69.30,69.15,49.22,31.42,22.47$.

(Mixture of isomers). 
4-(((E)-19-((R)-3-(4-amino-3-(4-phenoxyphenyl)-1H-pyrazolo[3,4-d]pyrimidin-1-

yl)piperidin-1-yl)-19-oxo-3,6,9,12,15-pentaoxanonadec-17-en-1-yl)oxy)-2-(2,6-

dioxopiperidin-3-yl)isoindoline-1,3-dione:
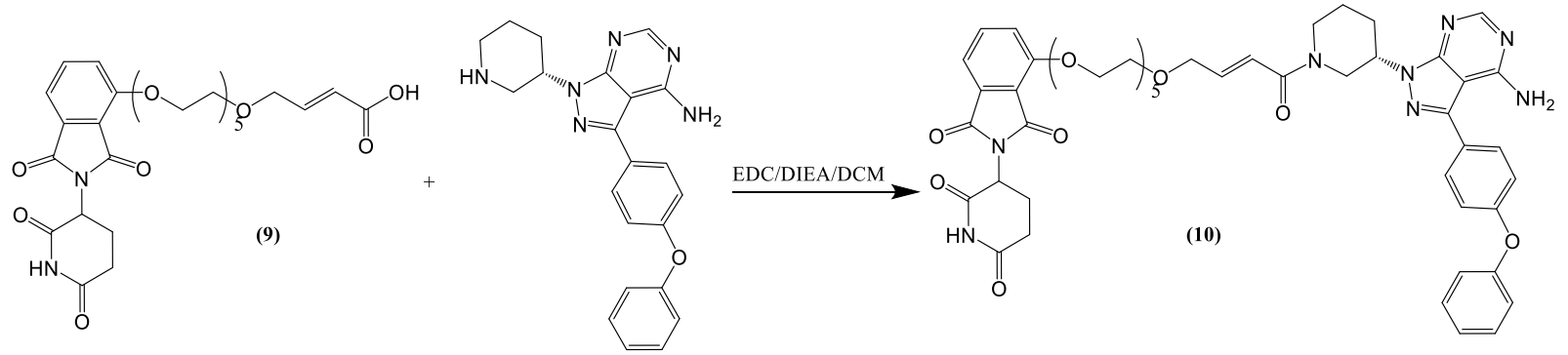

$3 \mathrm{mg}$ of $9(5.19 \mu \mathrm{mol})$ was dissolved in dry DCM on ice. 1.5 equivalents of 1-Ethyl-3-(3dimethylaminopropyl)carbodiimide hydrochloride $(1.5 \mathrm{mg})$ and $3 \mu \mathrm{l}$ diisopropylethylamine were added. After 5 minutes, 2 equivalents of the BTK inhibitor amine ( $4 \mathrm{mg}$ ) were added, and the reaction proceeded for 1 hour at room temperature. The solvent was evaporated and the product 10 was purified by HPLC as a white powder, $2.4 \mathrm{mg}$ ( $50 \%$ yield).

HR-MS (m/z): Calculated: 946.39; Found: $947.3911[\mathrm{M}+\mathrm{H}]^{+}, 969.3732[\mathrm{M}+\mathrm{Na}]^{+}$.

${ }^{1} \mathrm{H}$ NMR (500 MHz, DMSO-d 6 ) $\delta 11.11$ (s, 1H), 8.45 (s, 1H), 7.80 (t, J = 7.9 Hz, 1H), 7.70 $7.63(\mathrm{~m}, 2 \mathrm{H}), 7.53(\mathrm{~d}, \mathrm{~J}=8.6 \mathrm{~Hz}, 1 \mathrm{H}), 7.48-7.41(\mathrm{~m}, 3 \mathrm{H}), 7.24-7.19(\mathrm{~m}, 1 \mathrm{H}), 7.19-7.10$ (m, 4H), $6.68(\mathrm{~s}, 1 \mathrm{H}), 6.61-6.42(\mathrm{~m}, 1 \mathrm{H}), 5.09(\mathrm{dd}, \mathrm{J}=12.8,5.4 \mathrm{~Hz}, 1 \mathrm{H}), 4.84-4.64(\mathrm{~m}, 1 \mathrm{H})$, $4.59-4.48(\mathrm{~m}, 1 \mathrm{H}), 4.40-4.28(\mathrm{~m}, 2 \mathrm{H}), 4.19-3.96(\mathrm{~m}, 4 \mathrm{H}), 3.85-3.73(\mathrm{~m}, 3 \mathrm{H}), 3.69-3.60$ $(\mathrm{m}, 3 \mathrm{H}), 3.58-3.38(\mathrm{~m}, 16 \mathrm{H}), 2.94-2.82(\mathrm{~m}, 1 \mathrm{H}), 2.65-2.55(\mathrm{~m}, 1 \mathrm{H}), 2.31-2.19(\mathrm{~m}, 1 \mathrm{H})$, $2.19-2.09(\mathrm{~m}, 1 \mathrm{H}), 2.07-1.88(\mathrm{~m}, 2 \mathrm{H}), 1.67-1.52(\mathrm{~m}, 1 \mathrm{H})$.

${ }^{13} \mathrm{C}$ NMR (126 MHz, DMSO-d 6 ) $\delta$ 173.23, 170.38, 167.26, 165.71, 164.79, 158.69, 157.94, 156.62 , 156.29, 142.11, 141.62, 137.42, 133.69, 130.62, 124.36, 120.85, 120.49, 119.52, $119.45,117.48,116.77,115.84,115.15,97.54,70.62$, 70.29, 70.22, 70.18, 69.93, 69.78, 69.68, 69.32, 69.15, 53.41, 52.86, 49.74, 49.21, 46.16, 45.63, 42.09, 31.41, 29.98, 29.54, 25.24, 23.49, 22.46 ( 2 unaccounted for carbon peaks indicating some impurities) 
<smiles>CC(C)(C)OC(=O)NCCO</smiles><smiles>Cc1ccc(S(=O)(=O)OCCNC(=O)OC(C)(C)C)cc1</smiles>

(11)

$1 \mathrm{~g}$ of Boc-ethanolamine (6.2 mmol) was dissolved in dry DCM on ice, under argon. $2.4 \mathrm{~g}$ of tosyl chloride $(12.4 \mathrm{mmol})$ and $4.3 \mathrm{~mL}$ of triethylamine $(31 \mathrm{mmol})$ were added, and the reaction proceeded at room temperature for 3 hours. The reaction was quenched with ice, extracted three times with DCM, washed with $1 \mathrm{~N} \mathrm{HCl}, 5 \%$ sodium bicarbonate and water, dried over sodium sulfate and dried. The residue was purified using flash chromatography using a gradient of $0-10 \%$ methanol in chloroform, yielding a waxy solid, $1 \mathrm{~g}(50 \%)$.

${ }^{1} \mathrm{H}$ NMR (500 MHz, Chloroform-d) $\delta 7.81$ (d, J = 8.3 Hz, 2H), 7.37 (d, J = 8.0 Hz, 2H), 4.08 $(\mathrm{t}, \mathrm{J}=5.1 \mathrm{~Hz}, 2 \mathrm{H}), 3.45-3.32(\mathrm{~m}, 2 \mathrm{H}), 2.47(\mathrm{~s}, 3 \mathrm{H}), 1.42(\mathrm{~s}, 9 \mathrm{H})$.

${ }^{13} \mathrm{C}$ NMR (126 MHz, Chloroform-d) $\delta$ 145.0, 132.7, 123.0, 127.9, 79.8, 77.2, 69.5, 39.8, 28.3, 21.7 .

2-((2-(2,6-dioxopiperidin-3-yl)-1,3-dioxoisoindolin-4-yl)oxy)ethan-1-aminium:<smiles>O=C1CCC(N2C(=O)c3cccc(O)c3C2=O)C(=O)N1</smiles>

1. 11, $\mathrm{Na}_{2} \mathrm{CO}_{3} / \mathrm{DMF}$

2. TFA/DCM<smiles>CC(=O)[O-]</smiles>

$\mathbf{2}$ was reacted with $\mathbf{1 1}$ similar to the procedure for $\mathbf{3}$ and $\mathbf{8}$. The product was HPLC purified, deprotected with 25\% trifluoroacetic acid in DCM for 1 hour, and air-dried. The residue was 
lyophilized from 40\%:40\%:20\% acetonitrile:water:acetic acid to yield the acetate salt, yield $50 \%$.

${ }^{1} \mathrm{H}$ NMR (500 MHz, DMSO-d6) $\delta 11.12$ (br s, 1H), 8.05 (br s, 3H), 7.87 (dd, J = 8.5, 7.3 Hz, 1H), $7.56(\mathrm{dd}, \mathrm{J}=16.1,7.9 \mathrm{~Hz}, 2 \mathrm{H}), 5.11(\mathrm{dd}, \mathrm{J}=12.8,5.4 \mathrm{~Hz}, 1 \mathrm{H}), 4.45(\mathrm{t}, \mathrm{J}=5.2 \mathrm{~Hz}, 2 \mathrm{H})$, $3.28(\mathrm{~d}, \mathrm{~J}=10.8 \mathrm{~Hz}, 2 \mathrm{H}), 2.90(\mathrm{ddd}, \mathrm{J}=17.0,13.9,5.4 \mathrm{~Hz}, 1 \mathrm{H}), 2.65-2.53(\mathrm{~m}, 2 \mathrm{H}), 2.04$ (dtd, $\mathrm{J}=13.1,5.4,2.3 \mathrm{~Hz}, 1 \mathrm{H})$.

${ }^{13} \mathrm{C}$ NMR (126 MHz, DMSO-d 6 ) $\delta 173.24,170.34,167.16,165.70,155.50,137.58,133.73$, $121.18,118.50,117.54,116.72,66.58,49.27,38.60,31.40,22.49,21.51$.

(contains residual water).

(S,Z)-2-(3-(4-amino-3-(4-phenoxyphenyl)-1H-pyrazolo[3,4-d]pyrimidin-1-yl)piperidine-1carbonyl)hept-2-en-6-ynenitrile:
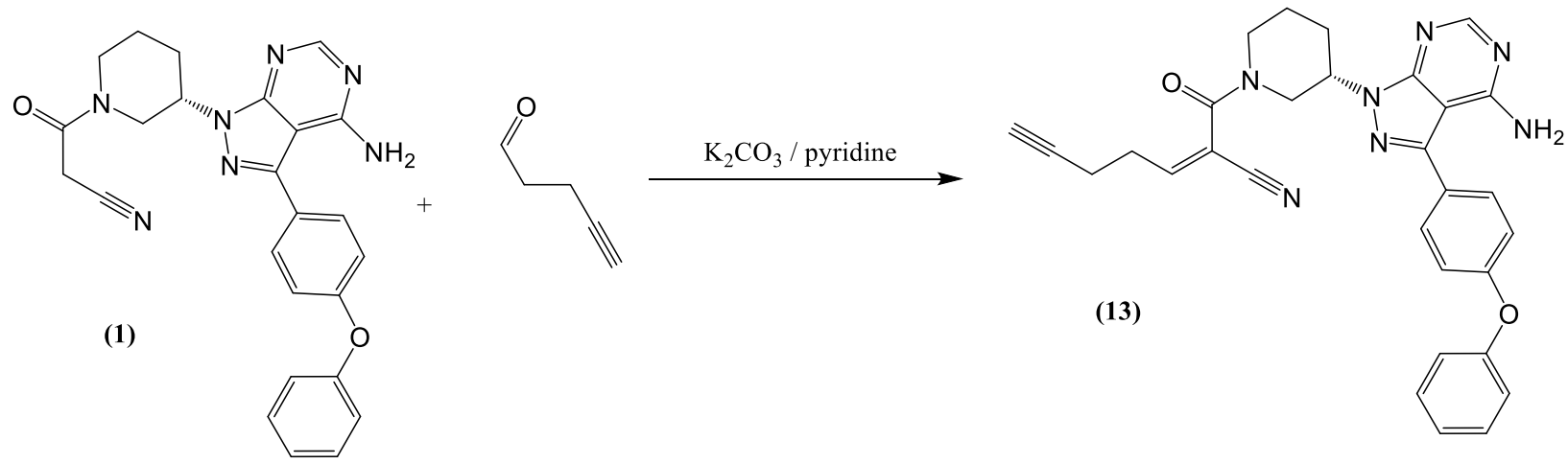

$40 \mathrm{mg}$ BTK cyanoacetate were reacted with $30 \mathrm{mg}$ 4-pentynal (4 eq) and 0.5 equivalents potassium carbonate in $4 \mathrm{~mL}$ pyridine at $50^{\circ} \mathrm{C}$. after 6 hours acetic acid was added, the solvent was evaporated and the product was purified by HPLC as a white powder, $15 \mathrm{mg}(33 \%)$.

Description of assembly of PROTAC series using combined click and amidation reactions:

Stock solutions were prepared in DMSO as follows: 12, $200 \mathrm{mM}$; VHL inhibitor hydrochloride (Molport), 200 mM; bifunctional PEG azide/NHS esters, $200 \mathrm{mM}$; Triethylamine, $0.5 \mathrm{M}$; 13, $200 \mathrm{mM}$; sodium ascorbate, $200 \mathrm{mM}$ in water, dissolved fresh; TBTA-copper complex, $50 \mathrm{mM}$ 
in 1:1 DMSO water (prepared by mixing equal volumes of $100 \mathrm{mM}$ Copper sulfate in water and $100 \mathrm{mM}$ TBTA in DMSO).

1. Reaction 1: $2 \mu \mathrm{mol}$ of E3 ligase binder with $2 \mu \mathrm{mol}$ of PEG reagents with 2.5 equivalents of triethylamine in DMSO (10 $\mu 1$ of each stock solution). Reactions were typically complete within 1 hour and monitored by LCMS.

2. Reaction 2: Mixed entire amidation reaction $(30 \mu 1$ of $67 \mathrm{mM})$ with $2.2 \mu \mathrm{mol} 13(11 \mu \mathrm{l})$, add $4 \mu \mathrm{mol}$ of sodium ascorbate $(20 \mu \mathrm{l}$ stock), $30 \mu \mathrm{l}$ water, $100 \mu \mathrm{l}$ tertbutanol, and $0.6 \mu 1$ TBTA:copper complex (12 $\mu$ l stock). Reaction was complete after 2 hours at room temperature.

Products were purified by HPLC, yielding 1-1.9 mg, 50-80\% yield.

2-((5-bromopentyl)oxy)tetrahydro-2H-pyran:

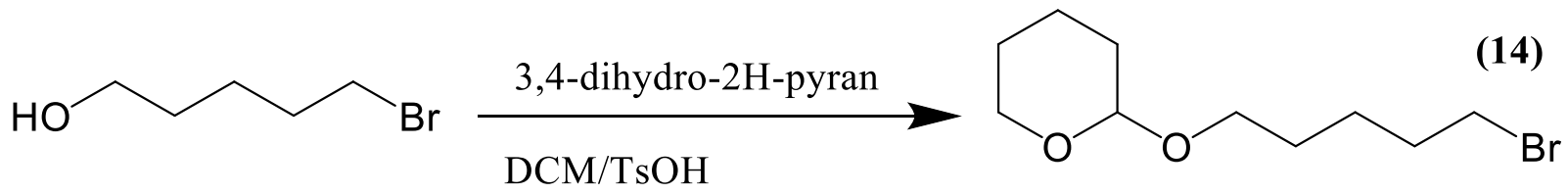

$1 \mathrm{~g}$ of 5-bromopentanol $(6.15 \mathrm{mmol})$ was dissolved in $20 \mathrm{~mL}$ dry $\mathrm{DCM}$ and cooled to $0^{\circ} \mathrm{C}$ on ice. $53 \mathrm{mg}$ of Toluenesulfonic acid hydrate was added, followed by dropwise addition of 0.78 $\mathrm{mL}$ 3,4-dihydro-2H-pyran (1.5 equivalents). Reaction proceeded on ice for 12 hours, stopped by addition of aqueous sodium bicarbonate, extracted with DCM, dried over sodium sulfate and evaporated. The residue was purified by flash chromatography hexane:diethylether 30:1. The product was obtained as a clear viscous liquid, $978 \mathrm{mg}$ (63\% yield).

${ }^{1} \mathrm{H}$ NMR (500 MHz, Chloroform-d) $\delta 4.59$ (dd, J = 4.4, $\left.2.7 \mathrm{~Hz}, 1 \mathrm{H}\right), 3.88$ (ddd, J = 11.0, 7.6, $3.2 \mathrm{~Hz}, 1 \mathrm{H}), 3.77$ (dt, J = 9.7, $6.6 \mathrm{~Hz}, 1 \mathrm{H}), 3.55-3.50(\mathrm{~m}, 1 \mathrm{H}), 3.47-3.38$ (m, 3H), 1.92 (p, $\mathrm{J}=7.0 \mathrm{~Hz}, 2 \mathrm{H}), 1.88-1.81(\mathrm{~m}, 1 \mathrm{H}), 1.76-1.71(\mathrm{~m}, 1 \mathrm{H}), 1.69-1.50(\mathrm{~m}, 8 \mathrm{H})$.

${ }^{13} \mathrm{C}$ NMR (126 MHz, Chloroform-d) $\delta$ 98.9, 67.2, 62.4, 33.8, 32.6, 30.8, 28.9, 25.5, 25.0, 19.7. 
17-((tetrahydro-2H-pyran-2-yl)oxy)-3,6,9,12-tetraoxaheptadecyl 4-methylbenzenesulfonate:

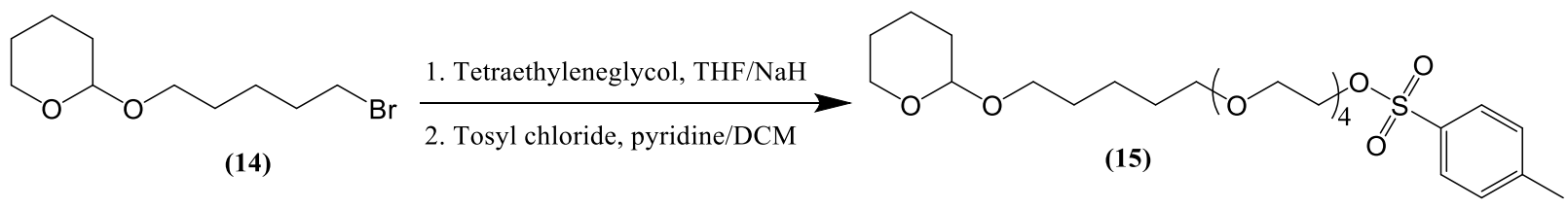

$8.13 \mathrm{mmol}$ tetraethylene glycol $(1.58 \mathrm{~g})$ were dissolved in dry THF and added slowly at room temperature to a stirring suspension of sodium hydride (327 mg slurry, $8.13 \mathrm{mmol}$ ). After 15 minutes at room temperature the reaction was heated to reflux and a solution of $611 \mathrm{mg}$ of $\mathbf{1 4}$ (2.42 mmol) in THF was added dropwise. The reflux was continued to reflux for 2.5 hours. The reaction was cooled to room temperature, water was added and the THF was evaporated. The product was extracted with DCM, washed with brine, dried over sodium sulfate and evaporated, yielding $620 \mathrm{mg}$ of crude product (dark yellow oil), which was used in the following step without purification. The product was dissolved in dry DCM on ice and 3 equivalents of pyridine ( $412 \mu \mathrm{l})$ were added. 1.5 equivalents of Tosyl chloride $(487 \mathrm{mg})$ were added in portions while stirring, and the reaction was warmed to room temperature and proceeded for 12 hours. The solvents was then evaporated, the residue was dispersed in a solution of $5 \%$ sodium bicarbonate in water, extracted with DCM, washed with brine and dried over sodium sulfate. The product was purified using flash chromatography using $0-10 \%$ methanol in chloroform, yielding 15 as a yellow oil, $405 \mathrm{mg}$ (32\%). Care was taken to avoid an acidic environment during the reactions and workups to avoid deprotection of the THP group.

${ }^{1} \mathrm{H}$ NMR (500 MHz, Chloroform-d) $\delta 7.81(\mathrm{~d}, \mathrm{~J}=8.2 \mathrm{~Hz}, 2 \mathrm{H}), 7.36(\mathrm{~d}, \mathrm{~J}=8.0 \mathrm{~Hz}, 2 \mathrm{H}), 4.58$ (dd, J = 4.5, 2.7 Hz, 1H), 4.26 - 4.09 (m, 2H), 3.88 (ddd, J = 11.0, 7.6, $3.2 \mathrm{~Hz}, 1 \mathrm{H}), 3.78-$ $3.32(\mathrm{~m}, 18 \mathrm{H}), 2.46(\mathrm{~s}, 3 \mathrm{H}), 1.90-1.33(\mathrm{~m}, 13 \mathrm{H})$.

${ }^{13} \mathrm{C}$ NMR (126 MHz, Chloroform-d) $\delta 144.8,133.0,129.8,127.9,98.9,71.4,70.8,70.6,70.6$, $70.6,70.5,70.1,69.2,68.7,67.5,62.4,30.8,29.6,29.5,25.5,22.8,21.7,19.7$. 
1-((2-(2,6-dioxopiperidin-3-yl)-1,3-dioxoisoindolin-4-yl)oxy)-3,6,9, 12-tetraoxaheptadecan-

17-al:
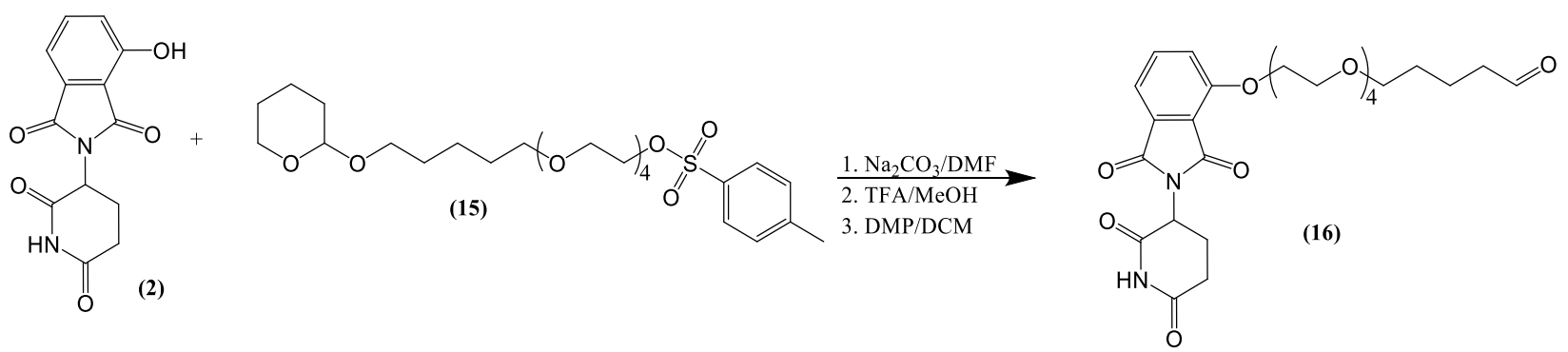

$124 \mathrm{mg}$ of $15(0.24 \mathrm{mmol})$ was reacted with 2 using the same conditions was described for 4 and 8. Following evaporation of the DMF, the residue was dissolved in methanol $+5 \%$ trifluoroacetic acid and stirred at room temperature. Full removal of the THP protecting group (as determined by LC-MS) was achieved within 1.5 hours. The solvent was evaporated and the free alcohol was purified using HPLC as a pale, viscous oil, $85 \mathrm{mg}$ (66\% yield). $72 \mathrm{mg}$ of the alcohol $(0.134 \mathrm{mmol})$ was dissolved in DCM and oxidized with $0.16 \mathrm{mmol}$ of dess martin periodinane $(68 \mathrm{mg})$ at $50^{\circ} \mathrm{C}$ for 2 hours. The solvent was evaporated and the residue was dissolved in 20\%:80\% acetonitrile:water $+0.1 \%$ TFA, filterd and purified using HPLC, yielding $53.6 \mathrm{mg}$ of the purified aldehyde $\mathbf{1 6}$ (75\% yield) as a pale, highly viscous oil.

HR-MS (m/z): Calculated: 534.22; Found: $557.2118[\mathrm{M}+\mathrm{Na}]^{+}$.

${ }^{1} \mathrm{H}$ NMR (500 MHz, DMSO-d 6 ) $\delta 11.11(\mathrm{~s}, 1 \mathrm{H}), 9.64-9.66(\mathrm{t}, \mathrm{J}=1.42 \mathrm{~Hz}, 1 \mathrm{H}), 7.89-7.72$ (m, 1H), $7.54(\mathrm{~d}, \mathrm{~J}=8.8 \mathrm{~Hz}, 1 \mathrm{H}), 7.46(\mathrm{~d}, \mathrm{~J}=7.3 \mathrm{~Hz}, 1 \mathrm{H}), 5.09(\mathrm{dd}, \mathrm{J}=12.9,5.4 \mathrm{~Hz}, 1 \mathrm{H}), 4.35$ $(\mathrm{dd}, \mathrm{J}=5.7,3.5 \mathrm{~Hz}, 2 \mathrm{H}), 3.81(\mathrm{dd}, \mathrm{J}=5.6,3.3 \mathrm{~Hz}, 2 \mathrm{H}), 3.70-3.61(\mathrm{~m}, 2 \mathrm{H}), 3.58-3.52(\mathrm{~m}$, 2H), $3.52-3.40(\mathrm{~m}, 10 \mathrm{H}), 3.36(\mathrm{t}, \mathrm{J}=6.1 \mathrm{~Hz}, 2 \mathrm{H}), 2.89(\mathrm{ddd}, \mathrm{J}=17.1,13.8,5.4 \mathrm{~Hz}, 1 \mathrm{H}), 2.66$ $-2.52(\mathrm{~m}, 2 \mathrm{H}), 2.09-1.96(\mathrm{~m}, 1 \mathrm{H}), 1.61-1.38(\mathrm{~m}, 4 \mathrm{H})$.

${ }^{13} \mathrm{C}$ NMR (126 MHz, DMSO-d 6 ) $\delta$ 203.89, 173.23, 170.38, 167.27, 165.71, 156.30, 137.44, $133.70,120.51,115.85,70.64,70.35,70.30,70.25,70.21,69.90,69.33,69.15,49.22,43.17$, $31.42,29.00,22.47,18.87$. 
(Z)-18-((S)-3-(4-amino-3-(4-phenoxyphenyl)-1H-pyrazolo[3,4-d]pyrimidin-1-yl)piperidine-1carbonyl)-1-((2-(2,6-dioxopiperidin-3-yl)-1,3-dioxoisoindolin-4-yl)oxy)-3, 6,9,12-

tetraoxanonadec-17-ene-19-nitrile
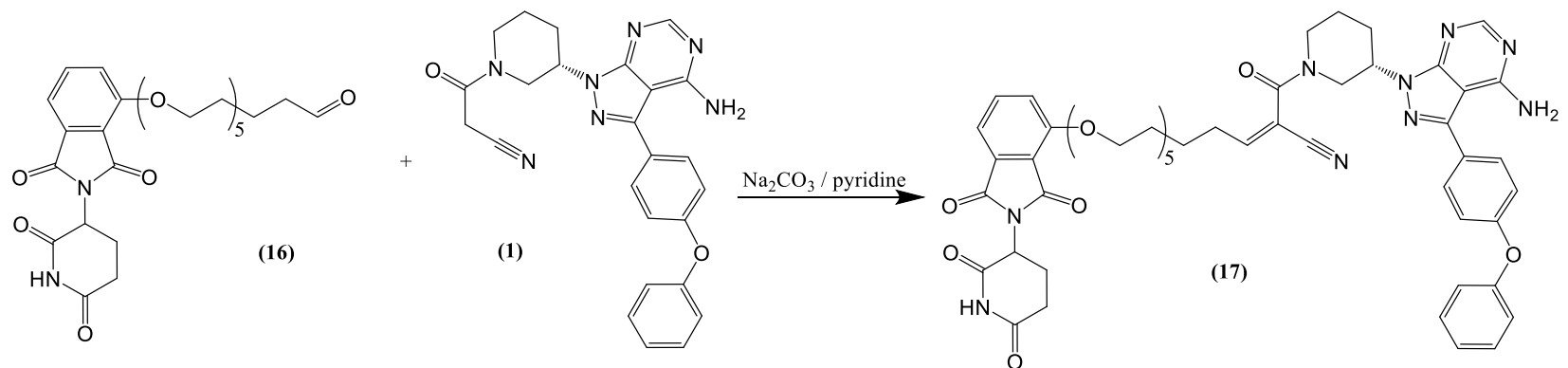

$43 \mathrm{mg}$ of $16(0.08 \mathrm{mmol})$ were dissolved in $1 \mathrm{~mL}$ of pyridine, and $36 \mathrm{mg}$ of $1(0.08 \mathrm{mmol})$ were also dissolved in $1 \mathrm{~mL}$ of pyridine. $4.24 \mathrm{mg}$ of sodium carbonate $(0.04 \mathrm{mmol})$ were added to the solution of $\mathbf{1}$, mixed RT for 5 minutes, and then the aldehyde was added. Reaction proceeded under argon at $50^{\circ} \mathrm{C}$ for 16 hours. Citric acid was added to neutralize the base and the solvent was evaporated. The product was purified by HPLC, giving $\mathbf{1 7}$ as a white powder, $19 \mathrm{mg}(25 \%$ yield).

HR-MS (m/z): Calculated: 969.40; Found: $970.4078[\mathrm{M}+\mathrm{H}]^{+}, 992.3896[\mathrm{M}+\mathrm{Na}]^{+}$.

${ }^{1} \mathrm{H}$ NMR (500 MHz, DMSO-d $) \delta 11.11(\mathrm{~s}, 1 \mathrm{H}), 8.45-8.37(\mathrm{~m}, 1 \mathrm{H}), 7.83-7.77(\mathrm{~m}, 1 \mathrm{H}), 7.67$ $(\mathrm{d}, \mathrm{J}=8.5 \mathrm{~Hz}, 2 \mathrm{H}), 7.53(\mathrm{~d}, \mathrm{~J}=8.5 \mathrm{~Hz}, 1 \mathrm{H}), 7.45(\mathrm{t}, \mathrm{J}=7.7 \mathrm{~Hz}, 3 \mathrm{H}), 7.24-7.09(\mathrm{~m}, 5 \mathrm{H}), 7.07$ $-6.81(\mathrm{~m}, 1 \mathrm{H}), 5.09(\mathrm{dd}, \mathrm{J}=12.8,5.4 \mathrm{~Hz}, 1 \mathrm{H}), 4.94-4.77(\mathrm{~m}, 1 \mathrm{H}), 4.34(\mathrm{t}, \mathrm{J}=4.5 \mathrm{~Hz}, 2 \mathrm{H})$, $3.80(\mathrm{t}, \mathrm{J}=4.4 \mathrm{~Hz}, 2 \mathrm{H}), 3.68-3.62(\mathrm{~m}, 2 \mathrm{H}), 3.59-3.10(\mathrm{~m}, 15 \mathrm{H}), 2.89$ (ddd, J = 17.0, 13.8, $5.4 \mathrm{~Hz}, 1 \mathrm{H}), 2.64-2.47(\mathrm{~m}, 3 \mathrm{H}), 2.46-2.12(\mathrm{~m}, 4 \mathrm{H}), 2.02(\mathrm{ddd}, \mathrm{J}=12.8,5.4,2.7 \mathrm{~Hz}, 2 \mathrm{H})$, $1.77-1.60(\mathrm{~m}, 1 \mathrm{H}), 1.56-1.35(\mathrm{~m}, 4 \mathrm{H})$.

${ }^{13} \mathrm{C}$ NMR (126 MHz, DMSO-d 6 ) $\delta 173.2,170.4,167.3,165.7,162.1,159.2,158.9,158.0$, 156.6, 156.3, 153.3 , 145.2, 137.4, 133.7, 130.6, 130.6, 127.4, 124.4, 120.5, 119.5, 119.5, 117.5, 116.8, 115.8, 115.2, 115.1, 110.9, 97.6, 70.6, 70.3, 70.2, 70.2, 69.9, 69.3, 69.2, 49.2, 31.5, 31.4, $29.1,24.5,22.5$. 


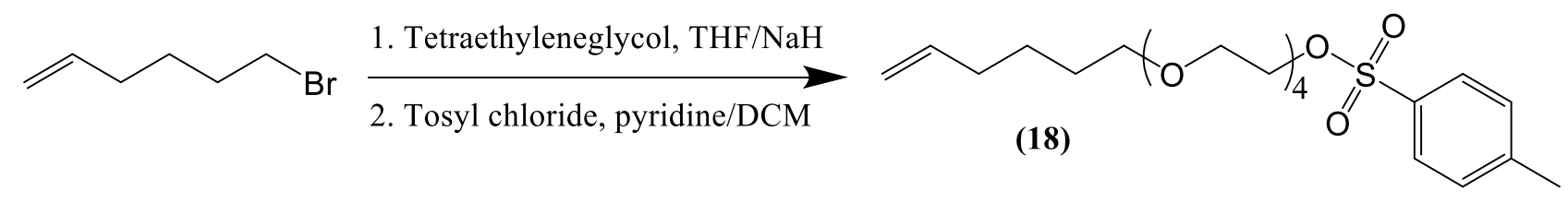

10 mmol PEG4 (1.94 g) was dissolved in dry THF and added dropwise to a suspension of 400 $\mathrm{mg} \mathrm{NaH/oil} \mathrm{dispersion} \mathrm{in} \mathrm{dry} \mathrm{THF} \mathrm{at} \mathrm{room} \mathrm{temperature} \mathrm{(400} \mathrm{mg} \mathrm{NaH} \mathrm{in} \mathrm{THF)} \mathrm{under} \mathrm{nitrogen.}$ After 30 minutes the reaction was heated to reflux and $3 \mathrm{mmol}$ 6-bromo-1-hexene (489 $\mathrm{mg}$ ) dissolved in THF was added to the solution while it refluxed. After 2 hours the reaction was cooled, neutralized with citric acid and water and the THF was evaporated. The product was extracted 3 times with DCM, washed with brine, dried over sodium sulfate and evaporated, resulting in $550 \mathrm{mg}$ of a brown oil, which was used without purification for the next step. The oil was dissolved in DCM, cooled on ice and $6 \mathrm{mmol}$ pyridine (484 $\mathrm{mg}$ ) was added. $3 \mathrm{mmol}$ of tosyl chloride $(576 \mathrm{mg}$ ) was added in portions, and after 30 minutes the reaction was warmed to room temperature and proceeded for 12 hours. The solution was evaporated, and the residue was dispersed in water and extracted with DCM. The organic phase was washed with brine, dried over sodium sulfate, and the crude material was purified using flash chromatography using a gradient of $0-6 \%$ methanol in chloroform. The product 18 was obtained as a light brown oil, $400 \mathrm{mg}$ (31\% yield).

${ }^{1} \mathrm{H}$ NMR (500 MHz, Chloroform-d) $\delta 7.82$ (d, J = 8.3 Hz, 2H), 7.36 (d, J = 8.0 Hz, 2H), 5.82 (ddt, J = 16.9, 10.2, $6.7 \mathrm{~Hz}, 1 \mathrm{H}), 5.02(\mathrm{dd}, \mathrm{J}=17.2,1.7 \mathrm{~Hz}, 1 \mathrm{H}), 4.96(\mathrm{~d}, \mathrm{~J}=10.3 \mathrm{~Hz}, 1 \mathrm{H})$, $4.20-4.16(\mathrm{~m}, 2 \mathrm{H}), 3.73-3.57(\mathrm{~m}, 14 \mathrm{H}), 3.47(\mathrm{t}, \mathrm{J}=6.7 \mathrm{~Hz}, 2 \mathrm{H}), 2.47(\mathrm{~s}, 3 \mathrm{H}), 2.11-2.04$ $(\mathrm{m}, 2 \mathrm{H}), 1.65-1.57(\mathrm{~m}, 2 \mathrm{H}), 1.50-1.40(\mathrm{~m}, 2 \mathrm{H})$.

${ }^{13} \mathrm{C}$ NMR (126 MHz, Chloroform-d) $\delta 144.8,138.8,133.0,129.8,128.0,128.0,114.5,71.3$, $70.8,70.6,70.6,70.5,70.1,69.2,68.7,33.5,29.1,25.4,21.7$.

HR-MS (m/z): Calculated: 430.20; Found: $453.1932[\mathrm{M}+\mathrm{Na}]^{+}, 469.1673[\mathrm{M}+\mathrm{K}]^{+}$. 
(E)-1-((2-(2,6-dioxopiperidin-3-yl)-1,3-dioxoisoindolin-4-yl)oxy)-3,6,9,12-tetraoxanonadec17-en-19-oic acid:
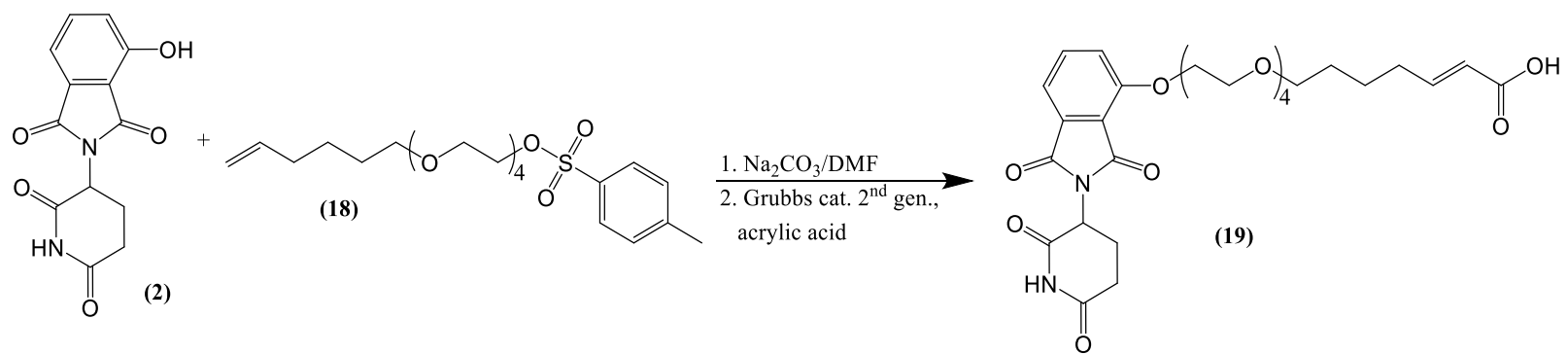

$94 \mathrm{mg}$ of $18(0.219 \mathrm{mmol})$ was reacted with $50 \mathrm{mg} 2(0.182 \mathrm{mmol})$ as described before. The product was purified by HPLC. $49.4 \mathrm{mg}$ product $(0.092 \mathrm{mmol})$ was dissolved in $1.5 \mathrm{~mL}$ dry THF and mixed with 30 equivalents of acrylic acid (190.4 $\mu 1) .0 .05$ equivalents of Grubbs catalysis $2^{\text {nd }}$ generation $\left(4 \mathrm{mg}\right.$ ) was adduct and the reaction was performed at $50^{\circ} \mathrm{C}$. The solvent was evaporated and the resulting acid was purified by HPLC as a yellow oil, $46.2 \mathrm{mg}(37 \%$ yield).

HR-MS (m/z): Calculated: 576.23; Found: $577.2393[\mathrm{M}+\mathrm{H}]^{+}, 599.2224[\mathrm{M}+\mathrm{Na}]^{+}$.

${ }^{1} \mathrm{H}$ NMR (500 MHz, DMSO-d $) \delta 11.11(\mathrm{~s}, 1 \mathrm{H}), 7.82(\mathrm{dd}, \mathrm{J}=8.5,7.2 \mathrm{~Hz}, 1 \mathrm{H}), 7.54(\mathrm{~d}, \mathrm{~J}=8.5$ $\mathrm{Hz}, 1 \mathrm{H}), 7.46(\mathrm{~d}, \mathrm{~J}=7.2 \mathrm{~Hz}, 1 \mathrm{H}), 6.80(\mathrm{dt}, \mathrm{J}=15.5,6.9 \mathrm{~Hz}, 1 \mathrm{H}), 5.75$ (d, J = 15.6 Hz, 1H), $5.09(\mathrm{dd}, \mathrm{J}=12.8,5.4 \mathrm{~Hz}, 1 \mathrm{H}), 4.35(\mathrm{dd}, \mathrm{J}=5.6,3.5 \mathrm{~Hz}, 2 \mathrm{H}), 3.83-3.79$ (m, 2H), 3.65 (dd, J $=5.8,3.7 \mathrm{~Hz}, 2 \mathrm{H}), 3.63-3.58(\mathrm{~m}, 4 \mathrm{H}), 3.54(\mathrm{dd}, \mathrm{J}=5.9,3.7 \mathrm{~Hz}, 2 \mathrm{H}), 3.46-3.43(\mathrm{~m}, 2 \mathrm{H})$, $3.37(\mathrm{t}, \mathrm{J}=6.1 \mathrm{~Hz}, 2 \mathrm{H}), 2.89(\mathrm{ddd}, \mathrm{J}=17.0,13.8,5.4 \mathrm{~Hz}, 1 \mathrm{H}), 2.63-2.56(\mathrm{~m}, 1 \mathrm{H}), 2.19-2.15$ (m, 2H), $2.06-1.98(\mathrm{~m}, 1 \mathrm{H}), 1.81-1.72(\mathrm{~m}, 5 \mathrm{H}), 1.53-1.38(\mathrm{~m}, 4 \mathrm{H})$.

${ }^{13} \mathrm{C}$ NMR (126 MHz, DMSO-d 6 ) $\delta 173.2,170.4,167.3,165.7,156.3,139.1,137.4,133.7$, $120.5,116.8,115.8,115.2,70.6,70.5,70.3,70.3,70.2,69.9,69.3,69.2,67.5,49.2,33.4,31.4$, $29.1,25.6,25.4,22.5$. 
4-(((E)-19-((S)-3-(4-amino-3-(4-phenoxyphenyl)-1H-pyrazolo[3,4-d]pyrimidin-1-

yl)piperidin-1-yl)-19-oxo-3,6,9,12-tetraoxanonadec-17-en-1-yl)oxy)-2-(2,6-dioxopiperidin-3yl)isoindoline-1,3-dione:
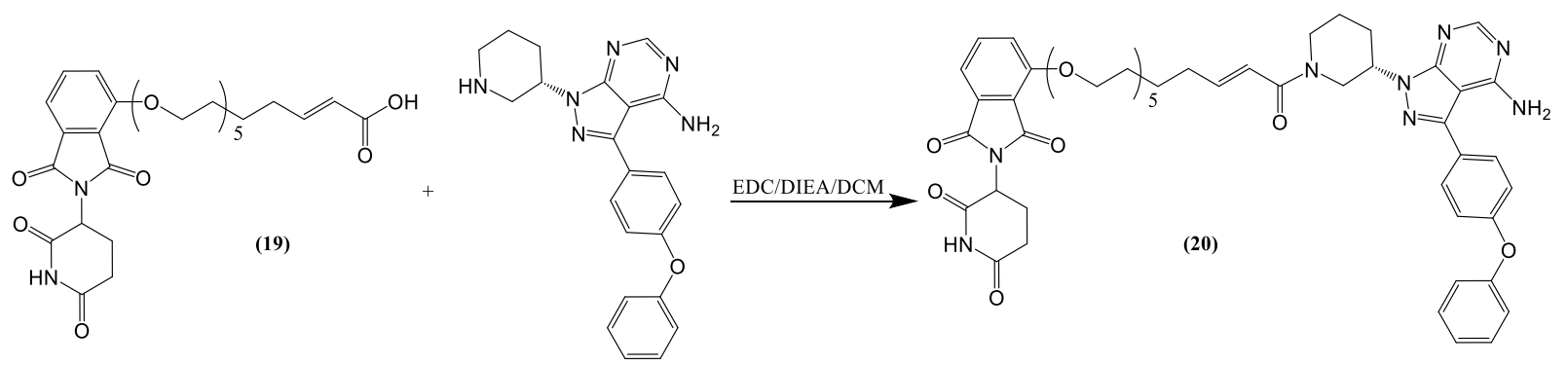

$16.5 \mathrm{mg}$ of $19(0.0286 \mathrm{mmol})$ were dissolved in DCM and stirred on ice. 1.5 equivalents of EDC $(5.5 \mathrm{mg})$ and 5 equivalents of DIEA $(25 \mu \mathrm{l})$ were added, and after 10 minutes, 2 equivalents of the BTK inhibitor amine $(22 \mathrm{mg}$ ) were added. The reaction proceeded at room temperature for 90 minutes, and then the solvent was evaporated and the product $\mathbf{2 0}$ was isolated using HPLC as a white powder, $12 \mathrm{mg}$ (44\% yield).

HR-MS (m/z): Calculated: 944.41; Found: $945.4130[\mathrm{M}+\mathrm{H}]^{+}, 967.3942[\mathrm{M}+\mathrm{Na}]^{+}$

${ }^{1} \mathrm{H}$ NMR (500 MHz, DMSO-d 6 ) $\delta 11.11(\mathrm{~s}, 1 \mathrm{H}), 8.39(\mathrm{~d}, \mathrm{~J}=6.1 \mathrm{~Hz}, 1 \mathrm{H}), 7.80(\mathrm{t}, \mathrm{J}=7.9 \mathrm{~Hz}$, 1H), $7.66(\mathrm{~d}, \mathrm{~J}=8.0 \mathrm{~Hz}, 2 \mathrm{H}), 7.53(\mathrm{~d}, \mathrm{~J}=8.5 \mathrm{~Hz}, 1 \mathrm{H}), 7.45(\mathrm{t}, \mathrm{J}=7.7 \mathrm{~Hz}, 3 \mathrm{H}), 7.24-7.06$ (m, $4 \mathrm{H}), 6.74-6.22(\mathrm{~m}, 2 \mathrm{H}), 5.09(\mathrm{dd}, \mathrm{J}=12.8,5.4 \mathrm{~Hz}, 1 \mathrm{H}), 4.80-4.47(\mathrm{~m}, 1 \mathrm{H}), 4.40-4.31(\mathrm{~m}$, $2 \mathrm{H}), 4.22-4.02(\mathrm{~m}, 2 \mathrm{H}), 3.80(\mathrm{~d}, \mathrm{~J}=4.1 \mathrm{~Hz}, 2 \mathrm{H}), 3.64(\mathrm{~d}, \mathrm{~J}=4.6 \mathrm{~Hz}, 2 \mathrm{H}), 3.56-2.99(\mathrm{~m}$, $16 \mathrm{H}), 2.89$ (ddd, J = 16.9, 13.9, $5.4 \mathrm{~Hz}, 1 \mathrm{H}), 2.63-2.54(\mathrm{~m}, 1 \mathrm{H}), 2.34-1.80(\mathrm{~m}, 7 \mathrm{H}), 1.66-$ $1.21(\mathrm{~m}, 6 \mathrm{H})$.

${ }^{13} \mathrm{C}$ NMR (126 MHz, DMSO-d 6 ) $\delta 173.2,170.4,167.3,165.7,165.2,157.9,156.7,156.3$, 146.1, 137.4, 133.7, 130.62, 124.4, 121.1, 120.5, 119.5, 119.5, 116.8, 115.8, 110.9, 97.6, 70.6, $70.4,70.3,70.2,70.2,69.9,69.3,69.2,49.2,46.2,31.8,31.4,29.2,24.9,22.5$. Not all ${ }^{13} \mathrm{C}$ signals could be detected. 


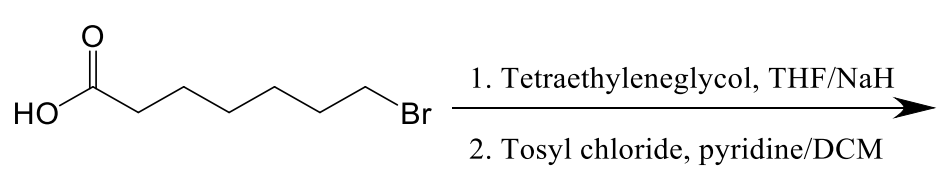
2. Tosyl chloride, pyridine/DCM<smiles>CCCOCCCCCCOS(=O)(=O)c1ccc(C)cc1</smiles>

(21)

$8.13 \mathrm{mmol}$ of tetraethylene glycol (1.58 g) were dissolved in dry THF and added to a slurry of sodium hydride mineral oil dispersion in THF at room temperature (423 mg). After 15 minutes the reaction was warmed to reflux and a solution of $511 \mathrm{mg}$ 7-bromoheptanoic acid $(2.42$ $\mathrm{mmol}$ ) in THF was added dropwise, and refluxed for 2 hours. The reaction was stopped by adding water and evaporating the THF. $\mathrm{HCl}$ was added to acidify the sample, and the sample was extracted with DCM, washed with brine, dried over sodium sulfate, and evaporated, giving $667 \mathrm{mg}$ of red oil. The product was tosylated as described for 17 and 15, yielding $47.6 \mathrm{mg}$ of the acid 21 (yield 4\%).

HR-MS (m/z): Calculated: 476.21; Found: $499.1986[\mathrm{M}+\mathrm{Na}]^{+}, 515.1710[\mathrm{M}+\mathrm{K}]^{+}$.

${ }^{1} \mathrm{H}$ NMR (500 MHz, Chloroform-d) $\delta 7.82(\mathrm{~d}, \mathrm{~J}=8.2 \mathrm{~Hz}, 2 \mathrm{H}), 7.36(\mathrm{~d}, \mathrm{~J}=8.0 \mathrm{~Hz}, 2 \mathrm{H}), 3.71$ (t, J = 4.9 Hz, 2H), $3.69-3.62(\mathrm{~m}, 8 \mathrm{H}), 3.62-3.57(\mathrm{~m}, 6 \mathrm{H}), 3.47$ (t, J = 6.5 Hz, 2H), 2.47 (s, $3 \mathrm{H}), 2.36(\mathrm{t}, \mathrm{J}=7.4 \mathrm{~Hz}, 2 \mathrm{H}), 1.68-1.58(\mathrm{~m}, 4 \mathrm{H}), 1.41-1.36(\mathrm{~m}, 4 \mathrm{H})$.

${ }^{13} \mathrm{C}$ NMR (126 MHz, Chloroform-d) $\delta 177.86,144.78,133.01,129.82,127.99,71.25,70.74$, 70.64, 70.61, 70.55, 70.50, 70.10, 69.24, 68.69, 33.68, 29.34, 28.77, 25.70, 24.61, 21.65. 
(S)-3-(4-phenoxyphenyl)-1-(piperidin-3-yl)-1H-pyrazolo[3,4-d]pyrimidin-4-amine 1-((2-(2,6dioxopiperidin-3-yl)-1,3-dioxoisoindolin-4-yl)oxy)-3, 6,9, 12-tetraoxanonadecan-19-oate:

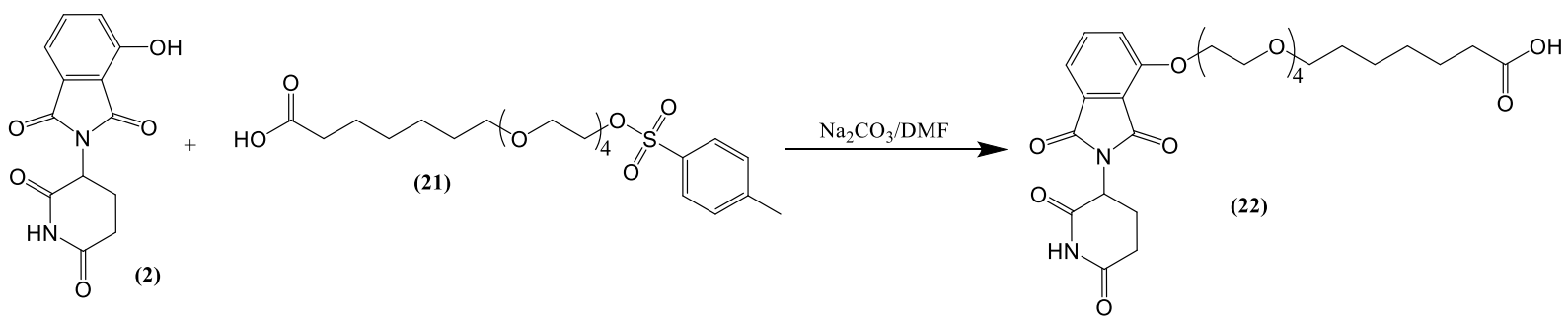

$36 \mathrm{mg}$ of $2(0.131 \mathrm{mmol})$ as dissolved in dry DMF and $70 \mathrm{mg}$ of sodium carbonate was added. The reaction was warmed to $100^{\circ} \mathrm{C}$ under nitrogen and a solution of $2 \mathrm{mg} 21(0.088 \mathrm{mmol})$ in DMF was added dropwise. The reaction continued for 2 hours, and the product was purified by HPLC, yielding $9 \mathrm{mg}$ of $\mathbf{2 2}$ as a yellow oil (18\% yield).

HR-MS (m/z): Calculated: 578.25; Found: $579.2552[\mathrm{M}+\mathrm{H}]^{+}, 601.2380[\mathrm{M}+\mathrm{Na}]^{+}$.

4-((19-((S)-3-(4-amino-3-(4-phenoxyphenyl)-1H-pyrazolo[3,4-d]pyrimidin-1-yl)piperidin-1yl)-19-oxo-3, 6,9,12-tetraoxanonadecyl)oxy)-2-(2,6-dioxopiperidin-3-yl)isoindoline-1,3-dione
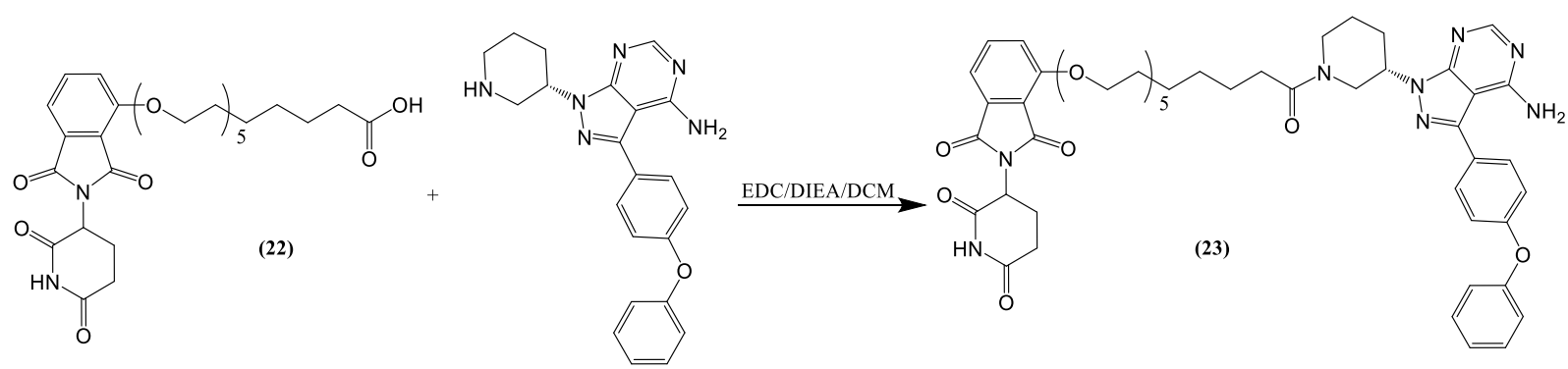

$4.5 \mathrm{mg}$ of $22(7.78 \mu \mathrm{mol})$ was dissolved in DCM and cooled on ice. 2 equivalents of EDC (3 $\mathrm{mg}), 2$ equivalents of hydroxybenzotriazole $(2.1 \mathrm{mg})$ and 4.5 equivalents of DIEA ( $4.7 \mu 1)$ were added, and the reaction proceeded for 10 minutes on ice. Then 3 equivalents of the BTK inhibitor amine $(7.5 \mathrm{mg})$ were added, and the reaction proceeded for 5 hours at room temperature. The product $\mathbf{2 3}$ was purified by HPLC and obtained as a white powder, $6.5 \mathrm{mg}$ ( $88 \%$ yield).

HR-MS (m/z): Calculated: 946.42; Found: $947.4299[\mathrm{M}+\mathrm{H}]^{+}, 969.4115[\mathrm{M}+\mathrm{Na}]^{+}$. 
${ }^{1} \mathrm{H}$ NMR (500 MHz, DMSO-d 6 ) $\delta 11.11(\mathrm{~s}, 1 \mathrm{H}), 8.38(\mathrm{~d}, \mathrm{~J}=3.7 \mathrm{~Hz}, 1 \mathrm{H}), 7.80(\mathrm{t}, 1 \mathrm{H}, \mathrm{J}=7.4$ Hz), 7.67 (dd, J = 8.5, 3.6 Hz, 2H), $7.53(\mathrm{dd}, \mathrm{J}=8.7,3.6 \mathrm{~Hz}, 1 \mathrm{H}), 7.49-7.42(\mathrm{~m}, 3 \mathrm{H}), 7.20$ (t, $\mathrm{J}=7.4 \mathrm{~Hz}, 1 \mathrm{H}), 7.19-7.15$ (m, 2H), $7.15-7.10$ (m, 2H), 5.09 (dd, J = 12.7, $5.3 \mathrm{~Hz}, 1 \mathrm{H}), 4.81$ - $4.72(\mathrm{~m}, 1 \mathrm{H}$, minor rotamer set A), $4.70-4.62(\mathrm{~m}, 1 \mathrm{H}$, major rotamer set $\mathrm{A}), 4.51(\mathrm{dd}, \mathrm{J}=$ 12.7, 4.2 Hz, 1H, major rotamer set B), $4.38-4.29$ (m, 2H), 4.19 (d, J = 12.9 Hz, 1H, minor rotamer set C), $4.03(\mathrm{dd}, \mathrm{J}=13.1,3.8 \mathrm{~Hz}, 1 \mathrm{H}$, minor rotamer set $\mathrm{B}), 3.87(\mathrm{~d}, \mathrm{~J}=13.6 \mathrm{~Hz}, 1 \mathrm{H}$, major rotamer set C), $3.84-3.75(\mathrm{~m}, 2 \mathrm{H}), 3.70-3.61(\mathrm{~m}, 2 \mathrm{H}), 3.56-3.52(\mathrm{~m}, 2 \mathrm{H}), 3.52-$ $3.40(\mathrm{~m}, 8 \mathrm{H}), 3.38-3.29(\mathrm{~m}, 2 \mathrm{H}), 3.18-3.09(\mathrm{~m}, 1 \mathrm{H}), 2.94-2.83(\mathrm{~m}, 2 \mathrm{H}), 2.66-2.53(\mathrm{~m}$, 2H), $2.40-2.08(\mathrm{~m}, 4 \mathrm{H}), 2.07-1.98(\mathrm{~m}, 1 \mathrm{H}), 1.97-1.84(\mathrm{~m}, 1 \mathrm{H}), 1.68-1.58(\mathrm{~m}, 1 \mathrm{H}$, major rotamer set D), $1.56-1.36(\mathrm{~m}, 5 \mathrm{H}), 1.33-1.16(\mathrm{~m}, 5 \mathrm{H})$.

${ }^{13} \mathrm{C}$ NMR (126 MHz, DMSO-d 6 ) $\delta$ 173.23, 171.33, 171.14, 170.37, 167.26, 165.71, 158.83, $158.55,157.91,157.86,156.64,156.30,153.60,153.24,144.96,144.62,137.43,133.70$, $130.62,130.55,127.68,127.55,124.36,120.50,119.51,119.45,117.52,116.78,115.84$, $115.19,97.65,97.52,70.73,70.63,70.30,70.24,70.22,69.93,69.91,69.33,69.15,53.44$, $52.88,49.69,49.21$, 45.71, 45.42, 41.48, 32.78, 31.42, 29.98, 29.75, 29.60, 29.56, 29.10, 25.99, $25.91,25.28,25.03,23.88,22.47$.

methyl 5-bromo-2,2-dimethylpentanoate:

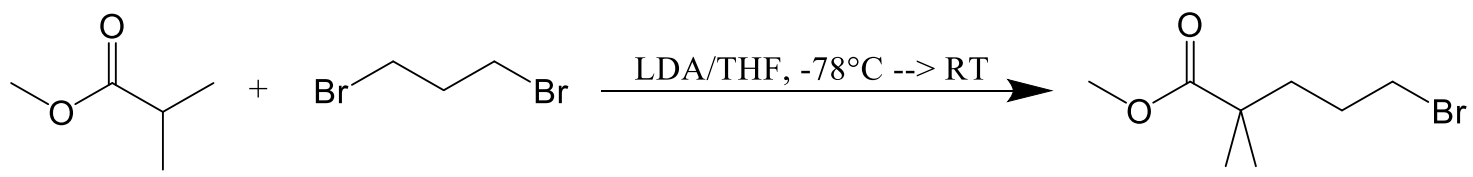

$25 \mathrm{~mL}$ of $2 \mathrm{M}$ lithium diisopropyl amide in THF/heptane (Sigma) was added to a flask at $-78^{\circ} \mathrm{C}$ under nitrogen. $5.5 \mathrm{~mL}$ ( $5 \mathrm{~g}, 0.05 \mathrm{~mol})$ of methyl isobutyrate was added dropwise while stirring. The reaction was stirred at $-78^{\circ} \mathrm{C}$ for an hour, and then $0.051 \mathrm{~mol}$ of 1,3 dibromopropane (4.2$4.3 \mathrm{~mL}$ ) was also added dropwise. After 1 hour of stirring at $-78^{\circ} \mathrm{C}$, the reaction was allowed to warm gradually to room temperature and then kept at room temperature for about 2 hours.

The reaction was poured over a solution of $5 \% \mathrm{NH}_{4} \mathrm{Cl}$ to quench it, and extracted with ethyl acetate three times. The organic fraction was washed once with $1 \mathrm{~N} \mathrm{HCl}$ and once with brine, followed by drying on sodium sulfate and evaporating. The product was purified using silica gel chromatorgraphy using a gradient of hexane to ethyl acetate, yielding $\mathbf{2 4}$ as a bright pink liquid at $\sim 80 \%$ purity based on TLC, yield $3.55 \mathrm{~g}(\sim 32 \%)$. 
The product was impure by NMR analysis, but comparison to a spectra of the ethyl ester analogue reported in the literature confirmed the presence of the desired product (Mueller et al, J. Med. Chem., 2004, 47, 6082-6099).

${ }^{1} \mathrm{H}$ NMR (300 MHz, Chloroform-d) $\delta 3.68$ (s, 3H), 3.39 (t, J = 6.5 Hz, 2H), $1.89-1.73$ (m, $2 \mathrm{H}), 1.72-1.61(\mathrm{~m}, 2 \mathrm{H}), 1.21(\mathrm{~s}, 3 \mathrm{H})$.

${ }^{13} \mathrm{C}$ NMR (75 MHz, Chloroform-d) $\delta$ 178.0, 51.8, 41.9, 39.2, 33.8, 28.5, 25.2.

5-bromo-2,2-dimethylpentan-1-ol:<smiles>COC(=O)C(C)(C)CCCBr</smiles>

$3.4 \mathrm{~g}$ of $24(0.0152 \mathrm{~mol})$ were reduced as follows. $0.6 \mathrm{~g}$ of lithium borohydride $(0.0275 \mathrm{~mol})$ were dispersed in dry DCM under nitrogen. $0.9 \mathrm{~mL}$ of dry methanol was added while the reaction was stirring inside a room temperature water bath to avoid excessive heating. The ester was then dissolved in DCM and added dropwise. The reaction was stirred under nitrogen overnight at $33^{\circ} \mathrm{C}$. The reaction was cooled on ice and quenched with cold saturated ammonium chloride solution for 1 hour with shaking. The phases were separated and the product extracted 3 times with $50 \mathrm{~mL}$ DCM, followed by two washes with $50 \mathrm{~mL}$ ammonium chloride (saturated) and 1 brine wash. The sample was dried over sodium sulfate, filtered through cotton and evaporated, giving $2.8 \mathrm{~g}$ of the alcohol 25 as a light pink liquid $(0.0143$ mol, 94\%). 25 was used at the next step without purification.

The product was impure by NMR analysis.

${ }^{1} \mathrm{H}$ NMR (300 MHz, Chloroform-d) $\delta 3.42$ (t, J = 6.9 Hz, 2H), 3.35 (s, 2H), $1.99-1.75$ (m, 2H), $1.46-1.30(\mathrm{~m}, 2 \mathrm{H}), 0.91(\mathrm{~s}, 6 \mathrm{H})$.

${ }^{13} \mathrm{C}$ NMR (75 MHz, Chloroform-d) $\delta 71.7,37.1,35.8,34.7,27.7,23.8$. 
2-((5-bromo-2,2-dimethylpentyl)oxy)tetrahydro-2H-pyran:

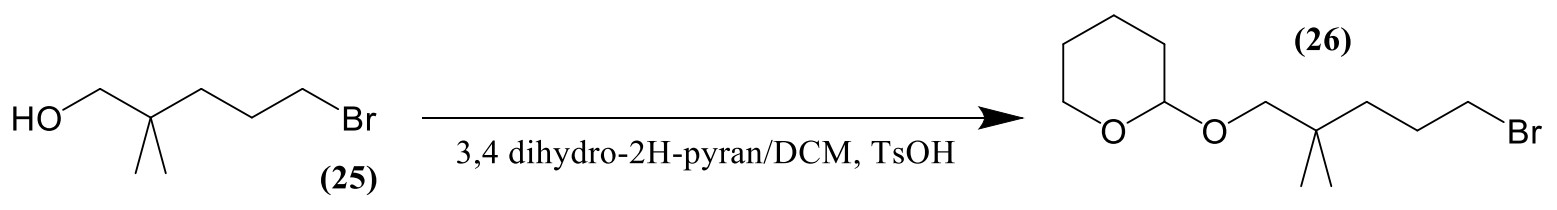

$2.3 \mathrm{~g}$ of $25(11.8 \mathrm{mmol})$ was dissolved in $30 \mathrm{~mL}$ dry $\mathrm{DCM}$ and cooled to $0^{\circ} \mathrm{C}$ on ice under nitrogen. 0.05 equivalents $(112 \mathrm{mg}$ ) of Toluenesulfonic acid hydrate was added, followed by dropwise addition of $2.15 \mathrm{~mL} \mathrm{3,4-dihydro-2H-pyran} \mathrm{(2} \mathrm{equivalents).} \mathrm{Reaction} \mathrm{proceeded} \mathrm{on}$ ice for 4-5 hours until the ice melted, stopped by addition of aqueous sodium bicarbonate, extracted with DCM, dried over sodium sulfate and evaporated. The sample was purified by flash chromatography using $2.5 \%$ diethyl ether in $97.5 \%$ hexane, yielding $\mathbf{2 6}$ as a colorless oil, yield $2.1 \mathrm{~g}(64 \%)$.

HR-MS (m/z): Calculated: 278.0881; Found: 301.0773 [M+Na] $]^{+}$

${ }^{1} \mathrm{H}$ NMR (300 MHz, Chloroform-d) $\delta 4.56(\mathrm{t}, \mathrm{J}=3.3 \mathrm{~Hz}, 1 \mathrm{H}), 3.96-3.77(\mathrm{~m}, 1 \mathrm{H}), 3.59-$ $3.46(\mathrm{~m}, 2 \mathrm{H}), 3.41(\mathrm{t}, \mathrm{J}=6.9 \mathrm{~Hz}, 2 \mathrm{H}), 3.01(\mathrm{~d}, \mathrm{~J}=9.2 \mathrm{~Hz}, 1 \mathrm{H}), 1.99-1.34(\mathrm{~m}, 10 \mathrm{H}), 0.93(\mathrm{~s}$, $3 \mathrm{H}), 0.92(\mathrm{~s}, 3 \mathrm{H})$.

${ }^{13} \mathrm{C}$ NMR (75 MHz, Chloroform-d) $\delta$ 99.1, 76.2, 62.0, 37.9, 34.8, 34.1, 30.6, 27.9, 25.6, 24.6, $24.5,19.4$.

16,16-dimethyl-17-((tetrahydro-2H-pyran-2-yl)oxy)-3,6,9,12-tetraoxaheptadecyl methylbenzenesulfonate<smiles>Cc1ccc(S(=O)(=O)O[Si](C)(C)OCCOCCCC(C)(C)COC2CCCCO2)cc1</smiles>

$8.13 \mathrm{mmol}$ tetraethylene glycol (1.58 g), was dissolved in dry THF and added slowly to a slurry of $327 \mathrm{mg} \mathrm{NaH}$ in dry THF. The reaction was heated to reflux. Then $675 \mathrm{mg}$ of $\mathbf{2 6}$ (2.42 mmol) were dissolved in dry THF and added dropwise to the solution under nitrogen. After 4 hours water was added and the THF was evaporated. Citric acid was added slowly until the $\mathrm{pH}$ was neutral (but not acidic to avoid THP removal). The sample was extracted with DCM, washed with Brine, filtered over sodium sulfate and evaporated. The sample was then dissolved in dry DCM, 3.5 equivalents of pyridine were added and the sample was cooled on ice. 1.5 equivalents 
of tosyl chloride were added in portions, and after 10 minutes on ice the reaction was warmed to room temperature and incubated overnight. The reaction was evaporated and dispersed in saturated sodium bicarbonate, extracted with DCM, washed with brine with added sodium bicarbonate to prevent acidification, filtered over sodium sulfate and purified by flash chromatography, yielding 27 as a viscous yellow oil, $221 \mathrm{mg}$ (17\% yield).

HR-MS (m/z): Calculated: 546.2863; Found: 569.2766 [M+Na $]^{+}$.

${ }^{1} \mathrm{H}$ NMR (400 MHz, Chloroform-d) $\delta 7.90(\mathrm{~d}, \mathrm{~J}=8.3 \mathrm{~Hz}, 2 \mathrm{H}), 7.44(\mathrm{~d}, \mathrm{~J}=8.0 \mathrm{~Hz}, 2 \mathrm{H}), 4.64$ $(\mathrm{t}, \mathrm{J}=3.5 \mathrm{~Hz}, 1 \mathrm{H}), 4.37-4.18(\mathrm{~m}, 2 \mathrm{H}), 3.98-3.88(\mathrm{~m}, 1 \mathrm{H}), 3.79(\mathrm{dd}, \mathrm{J}=5.6,4.1 \mathrm{~Hz}, 2 \mathrm{H})$, $3.75-3.71(\mathrm{~m}, 6 \mathrm{H}), 3.68(\mathrm{~s}, 5 \mathrm{H}), 3.62-3.48(\mathrm{~m}, 4 \mathrm{H}), 3.09$ (d, J = 9.1 Hz, 1H), 2.54 (s, 3H), $1.99-1.86(\mathrm{~m}, 1 \mathrm{H}), 1.83-1.74(\mathrm{~m}, 2 \mathrm{H}), 1.73-1.55(\mathrm{~m}, 6 \mathrm{H}), 1.42-1.33(\mathrm{~m}, 2 \mathrm{H}), 1.00(\mathrm{~s}$, $3 \mathrm{H}), 0.98(\mathrm{~s}, 3 \mathrm{H})$.

${ }^{13} \mathrm{C}$ NMR (101 MHz, Chloroform-d) $\delta 144.8,133.0,129.8,128.0,99.2,77.2,76.5,72.4,70.8$, $70.6,70.6,70.5,70.0,69.2,68.7,62.0,35.3,34.1,30.7,25.6,24.6,24.4,24.3,21.7,19.5$.

1-((2-(2,6-dioxopiperidin-3-yl)-1,3-dioxoisoindolin-4-yl)oxy)-16,16-dimethyl-3, 6,9,12tetraoxaheptadecan-17-al
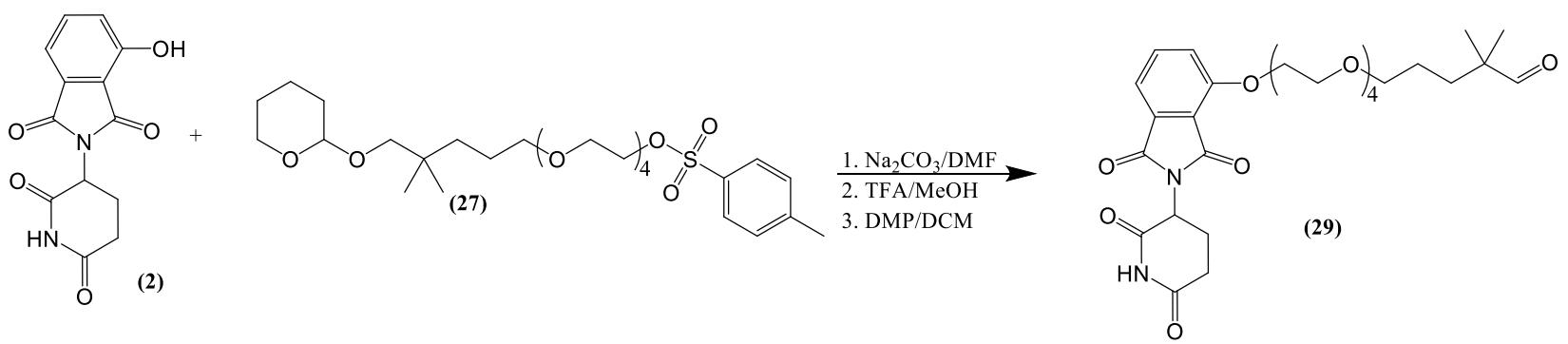

$100 \mathrm{mg}$ of $27(0.183 \mathrm{mmol})$ were dissolve in $200 \mu \mathrm{l}$ dry DMF. 1.5 equivalents of $2(75 \mathrm{mg})$ were dissolve in $300 \mu \mathrm{l} \mathrm{DMF}$ and 7.5 equivalents sodium carbonate (145 mg) were. Argon was bubbled through the sample and the solution was heated to $100^{\circ} \mathrm{C}$ followed by addition of the solution of 27. After 2 hours the DMF was evaporated and the residue was dissolved in $15 \mathrm{~mL}$ of $10 \%$ TFA in methanol. Deprotection was complete within 1 hour according to LC-MS. The methanol and TFA were evaporated and the thalidomide alcohol conjugate $\mathbf{2 8}$ was purified by HPLC as a high viscous pink oil, yield $63 \mathrm{mg}(61 \%)$.

HR-MS (m/z): Calculated: 564.2683; Found: $565.2750[\mathrm{M}+\mathrm{H}]^{+}$.

${ }^{1} \mathrm{H}$ NMR (400 MHz, DMSO-d 6 ) $\delta 11.18(\mathrm{~s}, 1 \mathrm{H}), 7.95-7.87(\mathrm{~m}, 1 \mathrm{H}), 7.62(\mathrm{~d}, \mathrm{~J}=8.5 \mathrm{~Hz}$, 1H), $7.55(\mathrm{~d}, \mathrm{~J}=7.2 \mathrm{~Hz}, 1 \mathrm{H}), 5.17(\mathrm{dd}, \mathrm{J}=12.8,5.4 \mathrm{~Hz}, 1 \mathrm{H}), 4.54-4.34$ (m, 2H), 3.89 (dd, 
$\mathrm{J}=5.6,3.5 \mathrm{~Hz}, 2 \mathrm{H}), 3.76-3.70(\mathrm{~m}, 2 \mathrm{H}), 3.66-3.34(\mathrm{~m}, 13 \mathrm{H}), 3.15(\mathrm{~s}, 2 \mathrm{H}), 3.03-2.92(\mathrm{~m}$, $1 \mathrm{H}), 2.72-2.62(\mathrm{~m}, 1 \mathrm{H}), 2.15-2.06(\mathrm{~m}, 1 \mathrm{H}), 1.54-1.46(\mathrm{~m}, 2 \mathrm{H}), 1.37-1.30(\mathrm{~m}, 1 \mathrm{H}), 1.28$ $-1.18(\mathrm{~m}, 2 \mathrm{H}), 0.85(\mathrm{~s}, 6 \mathrm{H})$.

${ }^{13} \mathrm{C}$ NMR (101 MHz, DMSO-d 6 ) $\delta 173.2,170.4,167.3,165.7,156.3,137.5,133.7,120.5$, $116.8,115.9,71.8,70.6,70.3,70.3,69.9,69.3,69.2,49.2,35.2,35.0,31.4,24.5,24.4,22.5$.

28 was then dissolved in dry DCM and 1.2 equivalents of dess martin periodinane were added (56.4 mg). The reaction proceeded at $45^{\circ} \mathrm{C}$ for three hours, filtered and evaporated. The residue was purified by HPLC, yielding $29 \mathrm{mg}$ of pure 29 (46 \% yield) as a viscous pink oil. HR-MS (m/z): Calculated: 562.2527; Found: $585.2430[\mathrm{M}+\mathrm{Na}]^{+}$.

${ }^{1} \mathrm{H}$ NMR (400 MHz, DMSO-d 6 ) $\delta 11.10$ (s, 1H), 9.40 (s, 1H), 7.81 (dd, J = 8.5, 7.2 Hz, 1H), $7.53(\mathrm{~d}, \mathrm{~J}=8.5 \mathrm{~Hz}, 1 \mathrm{H}), 7.46(\mathrm{~d}, \mathrm{~J}=7.2 \mathrm{~Hz}, 1 \mathrm{H}), 5.08$ (dd, J=12.8, 5.4 Hz, 1H), 4.34 (dd, J $=5.8,3.5 \mathrm{~Hz}, 2 \mathrm{H}), 3.80(\mathrm{t}, \mathrm{J}=4.6 \mathrm{~Hz}, 2 \mathrm{H}), 3.64(\mathrm{dd}, \mathrm{J}=5.9,3.7 \mathrm{~Hz}, 2 \mathrm{H}), 3.56-3.40(\mathrm{~m}$, 9H), $3.38-3.29$ (m, 6H), 2.88 (ddd, J = 17.0, 13.9, $5.4 \mathrm{~Hz}, 1 \mathrm{H}), 2.08-1.96(\mathrm{~m}, 1 \mathrm{H}), 1.55-$ $1.21(\mathrm{~m}, 4 \mathrm{H}), 1.13(\mathrm{~d}, \mathrm{~J}=3.5 \mathrm{~Hz}, 1 \mathrm{H}), 1.09-1.04(\mathrm{~m}, 1 \mathrm{H}), 0.96(\mathrm{~s}, 2 \mathrm{H}), 0.82(\mathrm{dd}, \mathrm{J}=10.0$, $7.1 \mathrm{~Hz}, 1 \mathrm{H})$.

${ }^{13} \mathrm{C}$ NMR (101 MHz, DMSO-d $)$ $\delta$ 207.1, 173.2, 170.4, 167.3, 165.7, 156.3, 137.5, 133.7, $120.5,116.8,115.9,49.2,45.5,40.6,38.5,35.3,35.2,33.5,31.4,29.8,27.8,27.6,25.4,24.6$, 24.6, 22.9, 22.5, 21.4 . 
18-((S)-3-(4-amino-3-(4-phenoxyphenyl)-1H-pyrazolo[3,4-d]pyrimidin-1-yl)piperidine-1carbonyl)-1-((2-(2,6-dioxopiperidin-3-yl)-1,3-dioxoisoindolin-4-yl)oxy)-16,16-dimethyl3,6,9,12-tetraoxanonadec-17-ene-19-nitrile
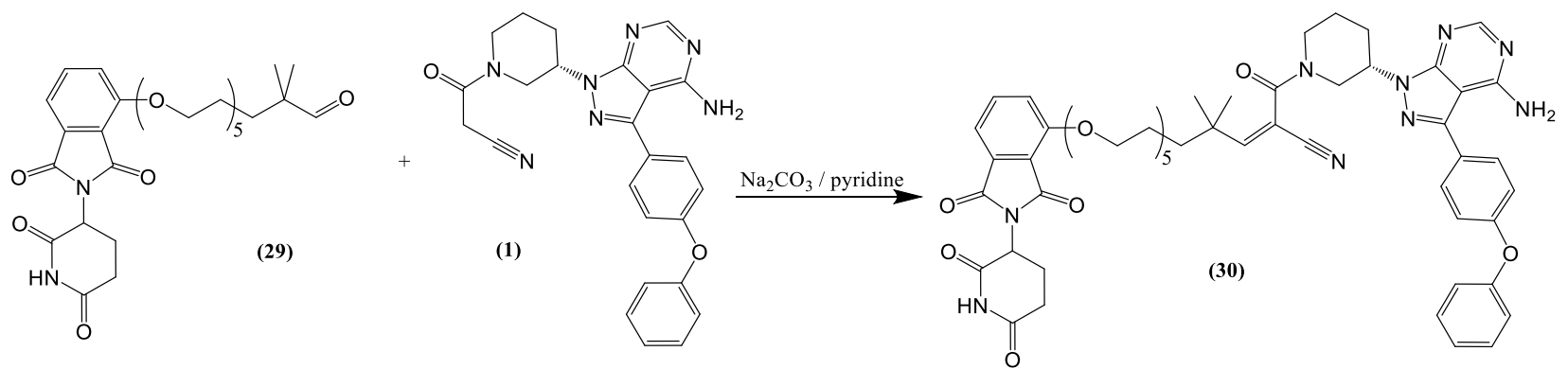

$7.27 \mathrm{mg}$ of $29(0.0129 \mathrm{mmol})$ and $5.84 \mathrm{mg}$ of $1(0.0129 \mathrm{~mol})$ were dissolved in pyridine (400 ul) and added to a pressure vessel. 5 equivalents of sodium carbonate $(6.8 \mathrm{mg})$ were added, the vessel was flushed with argon, and the reaction was warmed to $150^{\circ} \mathrm{C}$. After 50 hours citric acid was added to neutralize the reaction, the pyridine was evaporated, and the residue was purified by HPLC, yielding $\mathbf{3 0}$ as a white powder.

Not all expected 13C-NMR resonances could be detected.

HR-MS (m/z): Calculated: 997.4334; Found: $998.4390[\mathrm{M}+\mathrm{H}]^{+}$.

${ }^{1} \mathrm{H}$ NMR (400 MHz, DMSO-d $)$ ) $11.18(\mathrm{~s}, 1 \mathrm{H}), 8.37$ (s, 1H), 7.88 (t, J = 7.9 Hz, 1H), 7.74 (d, $\mathrm{J}=8.6 \mathrm{~Hz}, 2 \mathrm{H}), 7.60(\mathrm{~d}, \mathrm{~J}=8.6 \mathrm{~Hz}, 1 \mathrm{H}), 7.52(\mathrm{t}, \mathrm{J}=8.0 \mathrm{~Hz}, 2 \mathrm{H}), 7.34-7.15(\mathrm{~m}, 5 \mathrm{H}), 6.91-$ $6.71(\mathrm{~m}, 1 \mathrm{H}), 5.50(\mathrm{t}, \mathrm{J}=32.9 \mathrm{~Hz}, 2 \mathrm{H}), 5.16(\mathrm{dd}, \mathrm{J}=12.9,5.4 \mathrm{~Hz}, 1 \mathrm{H}), 4.96(\mathrm{~s}, 1 \mathrm{H}), 4.42(\mathrm{t}, \mathrm{J}$ $=4.5 \mathrm{~Hz}, 2 \mathrm{H}), 3.87(\mathrm{t}, \mathrm{J}=4.6 \mathrm{~Hz}, 2 \mathrm{H}), 3.77-3.67(\mathrm{~m}, 2 \mathrm{H}), 3.64-3.47(\mathrm{~m}, 13 \mathrm{H}), 2.96$ (ddd, $\mathrm{J}=17.3,14.1,5.4 \mathrm{~Hz}, 1 \mathrm{H}), 2.66(\mathrm{~d}, \mathrm{~J}=17.9 \mathrm{~Hz}, 1 \mathrm{H}), 2.44-2.30(\mathrm{~m}, 1 \mathrm{H}), 2.25(\mathrm{~d}, \mathrm{~J}=7.0 \mathrm{~Hz}$, $1 \mathrm{H}), 2.16-2.03(\mathrm{~m}, 2 \mathrm{H}), 1.99(\mathrm{~s}, 1 \mathrm{H}), 1.86-1.70(\mathrm{~m}, 1 \mathrm{H}), 1.64-1.05(\mathrm{~m}, 14 \mathrm{H})$.

${ }^{13} \mathrm{C}$ NMR $\left(101 \mathrm{MHz}, \mathrm{DMSO}-\mathrm{d}_{6}\right) \delta 173.2,170.4,167.3,165.7,163.4,162.9,160.0,157.7$, $156.7,156.3,137.4,133.7,130.6,130.5,128.1,124.3,120.5,119.5,119.4,116.8,115.8,108.2$, $97.8,70.6,70.3,70.2,70.2,69.9,69.3,69.2,49.2,31.4,29.5,26.6,26.5,22.5,21.5$. 


\section{References}

(1) Bradshaw, J. M.; McFarland, J. M.; Paavilainen, V. O.; Bisconte, A.; Tam, D.; Phan, V. T.; Romanov, S.; Finkle, D.; Shu, J.; Patel, V.; Ton, T.; Li, X.; Loughhead, D. G.; Nunn, P. A.; Karr, D. E.; Gerritsen, M. E.; Funk, J. O.; Owens, T. D.; Verner, E.; Brameld, K. A.; Hill, R. J.; Goldstein, D. M.; Taunton, J. Prolonged and Tunable Residence Time Using Reversible Covalent Kinase Inhibitors. Nat. Chem. Biol. 2015, 11 (7), 525-531. https://doi.org/10.1038/nchembio.1817.

(2) Cox, J.; Mann, M. MaxQuant Enables High Peptide Identification Rates, Individualized p.p.b.-Range Mass Accuracies and Proteome-Wide Protein Quantification. Nat. Biotechnol. 2008, 26 (12), 1367-1372. https://doi.org/10.1038/nbt.1511.

(3) Cox, J.; Hein, M. Y.; Luber, C. A.; Paron, I.; Nagaraj, N.; Mann, M. Accurate ProteomeWide Label-Free Quantification by Delayed Normalization and Maximal Peptide Ratio Extraction, Termed MaxLFQ. Mol. Cell. Proteomics 2014, 13 (9), 2513-2526. https://doi.org/10.1074/mcp.M113.031591.

(4) Sun, Y.; Zhao, X.; Ding, N.; Gao, H.; Wu, Y.; Yang, Y.; Zhao, M.; Hwang, J.; Song, Y.; Liu, W.; Rao, Y. PROTAC-Induced BTK Degradation as a Novel Therapy for Mutated BTK C481S Induced Ibrutinib-Resistant B-Cell Malignancies. Cell Res. 2018, 28 (7), 779-781. https://doi.org/10.1038/s41422-018-0055-1. 